INTIQAD: JURNAL AGAMA DAN PENDIDIKAN ISLAM

ISSN 1979-9950 (print) || ISSN 2598-0033 (online), http://jurnal.umsu.ac.id/index.php/intiqad

DOI: 10.30596/intiqad.v\%vi\%i.3752

Vol. 11, No. 2 (Desember 2019)

\title{
Resistansi Tradisi Kitab Kuning Pada Madrasah Al Washliyah Di Sumatera Utara
}

\author{
Muhammad Riduan Harahap ${ }^{1 *}$, Saiful Akhyar Lubis ${ }^{2}$ \\ Universitas Al Washliyah (UNIVA), Medan ${ }^{* 1}$ \\ Universitas Islam Negeri Sumatera Utara, Medan ${ }^{2}$ \\ ${ }^{*}$ email: wanhargaroga@gmail.com \\ 2email: saifulakhyarlubis@uinsu.ac.id
}

\begin{abstract}
Resistance of the tradition of learning the yellow book in the Al Washliyah madrassas departs from the following epistemological thoughts; (a). Thoughts about the primacy of religious knowledge (b). Mastery of the Yellow Book as the Main Criteria for Ulama, (c). Whereas the yellow book as part of the Al Washliyah sibgah (characteristic); (d). The consequences of self-engagement in the Ahl al-Sunnah Wa al-Jamâ'ah and the Shafi'i school of thought; and (e). Thoughts of belief in the results of the previous Ijtihad scholars. The effort to resist the tradition of learning the yellow book in the Al Washliyah madrassas is; (a). Efforts to silence religious science subject matter (b). The occurrence of a crisis of scholars; (c). Emerging and increasingly developed schools of thought or religious notions; and D). There is a negative impact on the development of internet technology. The forms of resistance in the tradition of book learning in the $\mathrm{Al}$ Washliyah madrasa are various, namely; (a) Consistently maintaining Al Washliyah's 100\% diniyah curriculum and refusing to apply the Department of Religion curriculum; (b). Modifying the curriculum, where the Al Washliyah madrasa accepts the Department of Religion curriculum, but by manipulating teaching materials / materials in the field; (c) Implement learning by combining Al Washliyah's diniyah curriculum and the Department of Religion's curriculum with a proportion of $70 \%$ of the diniyah curriculum and $30 \%$ of the Department of Religion's curriculum, as well as in other madrasas the ratio is $50 \%$ curriculum of diniyah and $50 \%$ of the Department of Religion's curriculum; (d). Develop extracurricular programs
\end{abstract}

\section{Keywords : Resistance of the Tradition of Learning the} Yellow Book, Al Washliyah Madrassas.. 


\section{Abstrak}

Resistansi tradisi pembelajaran kitab kuning di madrasah-madrasah Al Washliyah bertolak dari pikiranpikiran epistemologis berikut; (a). Pemikiran tentang keutamaan ilmu agama (b). Penguasaan Kitab Kuning Sebagai Kriteria Utama Ulama, (c). Bahwa kitab kuning sebagai bagian dari sibgah (ciri khas) Al Washliyah; (d). Konsekwensi dari pengikatan diri pada Aliran Ahl alSunnah Wa al-Jamâ'ah dan mazhab Syafi'i; dan (e). Pikiran keyakinan pada hasil-hasil Ijtihad ulama-ulama terdahulu. Resistansi tradisi pembelajaran kitab kuning di madrasahmadrasah Al Washliyah itu dilatar belakangi oleh; (a). Adanya upaya pendangkalan materi pelajaran ilmu agama (b). Terjadinya krisis ulama; (c). Muncul dan semakin berkembangnya aliran-aliran pemikiran atau paham-paham keagamaan; dan (d). Adanya dampak negatif perkembangan teknologi internet.

Resistansi tradisi pembelajaran kitab di madrasah Al Washliyah beragam bentuk yaitu; (a) Konsisten mempertahankan kurikulum diniyah Al Washliyah $100 \%$ dan menolak untuk menerapkan kurikulum Departemen Agama; (b). Melakukan modifikasi kurikulum, dimana madrasah Al Washliyah menerima kurikulum Departemen Agama, tetapi dengan merekayasa materi/bahan ajar di lapangan; (c) Menerapkan pembelajaran dengan memadukan kurikulum diniyah $\mathrm{Al}$ Washliyah dan kurikulum Departemen Agama dengan perbandingan porsi $70 \%$ kurikulum diniyah dan $30 \%$ kurikulum Departemen Agama, begitu juga pada madrasah yang lain perbandingannya $50 \%$ kurikulum diniyah dan $50 \%$ kurikulum Departemen Agama; dan (d). Mengembangkan program-program ekstrakurikuler.

\section{Kata Kunci : Resistansi Tradisi Kitab Kuning, Madrasah Al Washliyah}

\section{A. Pendahuluan}

Salah satu tujuan penting pendidikan Islam adalah memberikan pengetahuan dan pemahaman yang mendalam tentang ilmu-ilmu agama bagi umat agar mereka dapat menjalankan ajaran agamanya dengan baik. Saat AlGhazali mengklasifikasikan ilmu-ilmu agama (ulûm as-syar'iyah) sebagai ilmu 
fardu `ain, ${ }^{1}$ hal itu menujukkan betapa pengetahuan tentang ilmu-ilmu agama itu semestinya dijadikan sebagai prioritas utama di lembaga-lembaga pendidikan Islam. Para ulama juga mengeluarkan anjuran bahwa jika kemampuan seseorang tidak sanggup untuk menguasai semua disiplin ilmu, maka hendaknya ia lebih mengutamakan penguasaan ilmu-ilmu agama, karena ia merupakan ilmu paling mulia dan utama. Ilmu agama dipandang sebagai ilmu paling mulia dan utama, karena dengan mempelajarinya, maka seseorang akan mengetahui petunjuk tentang penegakan ibadah, sementara jika tidak mempelajarinya, maka seseorang akan sesat dalam pelaksanaan ibadah. ${ }^{2}$ Dengan demikian alasan pengutamaan ilmu agama itu dengan jelas berkaitan dengan pelaksanaan ibadah kepada Allah. Meskipun, sebagaimana menurut imam Syafi'i, bahwa ilmu agama itu sendiripun masih tetap membutuhkan beberapa disiplin ilmu lain, seperti matematika, bahasa, dan lainnya.

1 Abu Hâmid Muhammad al-Ghazâli, Mukhtașar Iyhâ Ulûmuddîn atau Al-Mursidul Amîn Ilâ Mauizatil Mu'minîn, (Mesir: Darul Kitab Islamiyah, 1340 H ), h. 111-114.

2 Abî al-Hasan'Ali bin Muhammad bin Habîb al-Bashri al-Mawardî, Âdab al-Dunyâ wa al-Dîn (Beirut: Dâr al-Fikr, 1995), h. 20-21.
Di kalangan umat Islam Indonesia, sejak awal, semangat mempelajari ilmuilmu agama itu sebenarnya sangat kuat, ditandai dengan menjamurnya lembagalembaga pendidikan Islam baik formal seperti madrasah maupun non formal seperti majelis-majelis taklim. Pengkajian ilmu-ilmu agama di berbagai lembaga tersebut biasanya berjalan dengan menggunakan kitab-kitab karya ulama klasik sebagai bahan kajian, yang kemudian lebih dikenal dengan istilah kitab kuning. Kaitan erat antara pengkajian ilmu-ilmu agama dengan kitab kuning telah membuat tradisi kitab kuning sedemikian familiar bagi umat Islam Indonesia. Bahkan, salah satu tolok ukur ulama bagi umat adalah berkaitaan dengan kemampuan mengakses kitab-kitab kuning. Kaitan erat itu juga terlihat pada kondisi dimana selain menjadi pusat orientasi studi, kitab kuning telah muncul sebagai suatu tata nilai yang kemudian menjadi acuan dalam menjalankan praktik keagamaan warga pesantren dan masyarakat muslim di sekitarnya. Hal itu juga menjadi suatu model yang mewarnai paham mereka. ${ }^{3}$

${ }^{3}$ Al-Rasyidin, "Pembelajaran Kitab Kuning di Pesantren Mustafawiyah, Mandailing 
Sedemikian familiarnya, sehingga tradisi pembelajaran kitab kuning tersebut tidak terbatas hanya pada lembaga-lembaga pendidikan formal seperti pesantren dan madrasah, tetapi tradisi itu juga hidup dan berkembang di lembaga-lembaga non formal, seperti pada majelis-majelis taklim atau kelompok-kelompok pengajian, baik yang dikelola oleh perseorangan maupun organisasi masyarakat.

Untuk daerah Sumatera Utara, selain di pesantren, tradisi pembelajaran kitab kuning itu juga hidup dan mentradisi di lingkungan madrasah, sebagaimana pada madrasah-madrasah milik Al Jam'iyatul Washliyah. Al Jam'iyatul Washliyah sebagai organisasi Islam terbesar di Sumatera Utara, memiliki sejumlah madrasah yang terkenal dengan tradisi pembelajaran kitab kuning yang kuat. Pada madrasahmadrasah tersebut, khususnya di tingkat Aliyah diajarkan kitab-kitab klasik (kitab kuning) dalam bidang Tafsir, Fiqih, Ușûl Fiqh, Qawâ'id Fiqh, Tasawuf, Tārikh dan lainnya, yang level kitabnya sejajar dengan kitab-kitab yang digunakan dalam kurikulum Universitas al Azhar-

Natal" Journal of Contemporary Islam And Muslim Societies.Vol. 1 No. 1 (2017), h. 42.
Mesir. Karena tingginya penguasaan kitab-kitab tersebut, tidak mengherankan bahwa sampai dengan tahun 1960-an, kemampuan belajar alumni dari madrasah-madrasah Qismul Ali AlJam'iyatul Washliyah dipandang sudah setara dengan mahasiswa tingkat Dirâsyah Ulyâ (Magister) di beberapa perguruan tinggi yang ada di Timur Tengah seperti Universitas al-Azhar di Mesir dan Universitas Islam Negeri (Jâmi`ah Islâmiyah al-Hukûmiyah) di Libya. Dengan demikian, mereka biasanya selalu diterima untuk kuliah di sana tanpa tes sebagaimana umumnya. ${ }^{4}$

Dalam pembinaan keagamaan umat, madrasah-madrasah Al Washliyah telah berhasil melahirkan para ustaz dan ulama yang handal dalam menyampaikan ilmu-ilmu agama bagi masyarakat Sumatera Utara dengan kemampuan yang sangat baik dalam membaca atau mengakses kitab-kitab kuning. Bahkan kedalaman pengetahuan dan pemahaman ilmu-ilmu agama dengan kemampuan mengakses kitab kuning di kalangan ulama Al Washliyah itu lah yang menempatkan organisasi

\footnotetext{
${ }^{4}$ Muhammad Rozali, Tradisi Keulamaan Al Jam'iyatul Washliyah Sumatera Utara (Yogyakarta: LKiS, 2017), h. 44.
} 
INTIQAD: JURNAL AGAMA DAN PENDIDIKAN ISLAM

ISSN 1979-9950 (print) || ISSN 2598-0033 (online), http://jurnal.umsu.ac.id/index.php/intiqad DOI: 10.30596/intiqad.v\%vi\%i.3752

Vol. 11, No. 2 (Desember 2019) tersebut terkenal sebagai lumbung ustaz dan ulama bagi masyarakat, khususnya di Sumatera Utara.

Kuatnya tradisi pembelajaran kitab kuning di madrasah-madrasah $\mathrm{Al}$ Washliyah tersebut merupakan konsekwensi logis dari cara pandang warga atau ulama Al Washliyah terhadap signifikansi posisi kitab kuning tersebut yang terlihat dalam dua hal. Pertama, bahwa otentisitas kitab kuning dalam pandangan para ulama Al Washliyah merupakan refrensi yang kandungannya sudah tidak perlu dipertanyakan lagi. Kedua, bagi warga atau ulama $\mathrm{Al}$ Washliyah, kitab kuning merupakan cermin dari cakrawala pemikiran keagamaan yang lahir dan berkembang di sepanjang sejarah peradaban Islam. Karenanya, untuk menjadikan $\mathrm{Al}$ Washliyah tetap sebagai pusat kajian keislaman, maka pemeliharaan dan bahkan pengayaan kitab kuning harus menjadi ciri utamanya. ${ }^{5}$

\section{Berkembangnya} ide-ide modernisasi akhir abad 19 telah merubah wajah madrasah yang awalnya demikian identik dengan kajian ilmu-ilmu agama, namun belakangan terlihat lebih terkesan sebagai sekolah umum. Karenanya, bagi

5Ibid., h. 90. sebagian masyarakat Indonesia, modernisasi yang demikian itu dipandang sebagai sebuah ancaman, khusunya mereka yang masih memegang teguh tradisi tertentu, yang pada akhirnya telah menimbulkan sikap penolakan atau setidaknya sikap enggan untuk mengikutinya. Begitu juga dengan dunia pendidikan, bahwa sebagian besar ulama atau kiyai-kiyai yang memimpin atau mengajar di lembaga-lembaga pendidikan Islam, menunjukkan sikap yang sangat hati-hati bahkan tidak sedikit yang menolak ide-ide modernisasi tersebut. Sebagaimana ditegaskan oleh Karel Steenbrink bahwa lembaga-lembaga pendidikan Islam tradisional sejak awal telah menunjukkan sikap penolakan terhadap modernisasi itu. Menurutnya, dalam konteks surau tradisional sebagaimana yang terdapat di daerah Minangkabau misalnya, menunjukkan sikap "menolak dan mencontoh" ide-ide modernisasi, sementara itu di kalangan pesantren yang dominan terdapat di wilayah Jawa menunjukkan sikap yaitu "menolak sambil mengikuti” ide-ide modernisasi. ${ }^{6}$

6 Karel A. Steenbrink, Pesantren, Madrasah, Sekolah: Pendidikan Islam dalam Kurun Modern (Jakarta: LP3ES, 1991), h. 62-72. 
Sikap enggan atau penolakan terhadap ide-ide modernisasi itu juga terlihat jelas di kalangan pemimpin surau di wilayah Padang. Dalam suatu rapat yang dilakukan olehpara ulama tradisional yang tergabung dalam Persatuan Tarbiyah Islamiyah (PERTI) di rumah Sulaiman Ar-Rasuli-seorang pemilik surau di Candung (sekitar 9 KM dari Bukit Tinggi), membicarakan tentang ancaman pembaharuan terhadap eksistensi surau. Rapat tersebut dihadiri oleh beberapa ulama yang dalam hal-hal tertentu tidak setuju dengan aliran pendidikan Madrasah Diniyah (modern) yaitu Sumatera Thawalib dan PGAI atau kelompok kaum muda. Dalam rapat inimuncul kesadaran dan keterkejutan mereka terhadap kenyataan bahwa surau yang mereka miliki itu tidak begitu laku lagi, bahkan mulai kosong karena banyaknya siswa mereka yang pindah ke madrasah diniyah Sumatera Thawalib yang untuk ukuran saat itu sudah tergolong modern. Karenanya, pada pertemuan tersebut, mereka yang digolongkan seabagai para ulama tradisional itu-secara mau tidak mau memutuskan untuk mengambil ide-ide modernisasi itu, namun yang diikuti hanya beberapa unsurnya saja seperti sistem kalsikal, sebagaimana misalnya yang dilakukan oleh Syaikh Abbas dari Ladang Lawas dengan mendirikan Arabiyah School pada tahun 1918 dan mendirikan sekolah kedua di Bukit Tinggi dengan sistem klasikal. ${ }^{7}$

Namun faktanya, meski di awalawal, sebagian pesantren dan madrasah menunjukkan sikap hati-hatinya dan bahkan sebagiannya berupaya menolak modernisasi itu, namun pada akhirnya, dalam keadaan terpaksa dan demi untuk menjamin keberlangsungan eksistensinya, secara umum lembagalembaga pendidikan Islam itu pun mengikuti ide-ide modernisasi tersebut. ${ }^{8}$ Saat lembaga-lembaga pendidikan Islam itu mulai mengikuti pola-pola modernisasi, maka sejak itu pula lah mereka mulai kehilangan tradisi-tradisi yang dimiliki termasuk tradisi pembelajaran kitab kuning.

Tradisi pembelajaran kitab kuning yang awalnya mengakar begitu kuat di lembaga-lembaga pendidikan Islam itu, secara perlahan mulai pudar dan kualitas maupun kuantitasnya menurun.

${ }^{7}$ Ibid., h. 63-64.

8 Nor Huda, Sejarah Sosial Intelektual Islam di Indonesia (Jakarta: RajaGrafindo Persada, 2015), h. 314-315. 
Demikian halnya di madrasah-madrasah, terlebih setelah diterbitkannya SKB Tiga Menteri pada tahun 1975 telah mengalami perubahan yang sangat besar di bidang kurikulum dengan pengurangan jumlah mata pelajaran agama yang dengan sendirinya juga telah mengikis tradisi kitab kuning tersebut. Di samping karena jumlah jam yang berkurang, kualitas pembelajarannya pun mengalami penurunan. Perubahanperubahan yang dilakukan, khususnya berkaitan dengan kurikulum itu telah menyebabkan penguasaan para siswa atau santri terhadap kitab kuning menjadi sangat rendah. Kitab-kitab kuning tidak begitu diperhatikan lagi oleh lembaga-lembaga pendidikan Islam, meskipun sebagian kecil pesantren, seperti pesantren Mustafawiyah di Mandailing Natal melakukan siasat dengan cara mengajarkan kurikulum ilmu-ilmu agama dengan kitab kuning dari pagi sampai siang hari, dan mengajarkan ilmu-ilmu yang terdapat dalam kurikulum SKB Tiga Menteri di sore harinya. ${ }^{9}$

Untuk madrasah-madrasah di lingkungan Al Washliyah khususnya di Sumatera Utara, penurunan kualitas dan kuantitas pengajaran kitab kuning itu pun terjadi sangat drastis. Penelitian Muhammad Rozali menemukan data bahwa dari 462 jumlah madrasah yang terdapat di bawah naungan AlJam'iyatul Washliyah di Sumatera Utara, saat ini tinggal hanya sekitar 4 sampai dengan 5 madrasah lah yang memiliki komitmen dan kemaua untuk tetap mempertahankan dan menggunakan kitab kuning baik pada tingkat dasar (ibtidāiyah), menengah (sanawiyah), dan tinggi (āliyah). ${ }^{10}$

Menyaksikan keadaan tersebut, maka tergerak semangat yang cukup signifikan pada diri sebagian pengelola lembaga pendidikan untuk terus mempertahankan, bahkan tidak hanya itu tetapi lebih menghidupkan tradisi kitab kuning, baik melalui jalur formal maupun non formal. Untuk wilayah Aceh misalnya, upaya mempertahankan tradisi kitab kuning tersebut dapat dilihat pada kasus Dayah Mudi Mesjid Raya Simalanga Bireuen Aceh. Dalam kurikulum dayah tersebut, khususnya pada jenjang ketiga (Takhașşus Ma'had 'Ali) dimana selain memasukkan pengetahuan umum seperti Bahasa Indonesia, Bahasa Inggris, Matematika,

\footnotetext{
${ }^{9}$ Al-Rasyidin, Pembelajaran, h. 55.
} 
Komputer, Filsafat Umum, Metodologi Penelitian, Manajemen Pendidikan, Pengantar Ilmu Hukum, Ilmu Komunikasi, dan Hukum Perdata, juga tetap mempertahankan ilmu-ilmu agama dengan mewajibkan "kitab-kitab kuning" sebagai bahan ajarnya. ${ }^{11} \mathrm{Hal}$ ini menunjukkan bahwa di tengah tarikan modernisasi itu sebenarnya ada upaya lembaga-lembaga pendidikan Islam untuk mempertahankan tradisi-tradisi yang sudah berakar sebelumnya.

Di lingkungan Al Washliyah, upaya mempertahankan tradisi kitab kuning itu dilakukan melalui jalur formal maupun non formal. Lewat lembaga formal, upaya mempertahankan tradisi itu ditempuh dengan mendirikan madrasah-madrasah. Catatan sejarah menunjukkan bahwa ketika lembaga pendidikan formal belum begitu populer di kalangan masyarakat Islam, para tokoh Al Washliyah sudah mulai merancang format, jenjang, dan kurikulum pendidikan formal sehingga terbentuklah madrasah pertama $\mathrm{Al}$

${ }^{11}$ Zulfikar Ali Buto Siregar, Modernisasi Dayah di Aceh (Disertasi, UIN Sumatera Utara, 2015), h. 148.
Washliyah yang terletak di Jalan Srinagar Medan. ${ }^{12}$

Peran itu terus dijalankan oleh madrasah Al Washliyah hingga saat ini meskipun dalam ritme yang fluktuatif. Hingga saat ini terdapat beberapa Madrasah yang tetap bertahan menjadikan kitab kuning sebagai ciri khas pendidikan dalam rangka penjagaan tradisi keulamaan di Kota Medan, seperti di Madrasah Tsanawiyah Mu'allimīn UNIVA Medan, Madrasah Āliyah Mu'allimīn UNIVA Medan, dan Madrasah al-Qismul 'Āli Ismāiliyah Medan. Madrasah-madrasah ini merupakan madrasah plus yang berorientasi pada sistem pendidikan Nasional sekaligus sistem pendidikan Al Washliyah dengan penekanan pada kajian kitab-kitab klasik (kitab kuning). Sementara melalui lembaga non formal, Al Washliyah berupaya mempertahankan dan melestarikan tradisi kitab kuning dengan mengadakan pengajian kitab kuning seperti yang dirintis oleh Lahmuddin Nasution (19502007) dan ulama-ulama Al Washliyah lainnya bertempat di UNIVA Medan.

12 Saiful Akhyar Lubis (Ed.), Peran Moderasi Al Washliyah (Medan: UNIVA Press, 2009), h. 55. 
ISSN 1979-9950 (print) || ISSN 2598-0033 (online), http://jurnal.umsu.ac.id/index.php/intiqad

DOI: 10.30596/intiqad.v\%vi\%i.3752

Vol. 11, No. 2 (Desember 2019)

\section{B. Pembahasan}

\section{Tradisi Kitab Kuning di} Madrasah

Tumbuh dan berkembangnya madrasah di Indonesia tidak terlepas dari madrasah-madrasah yang tumbuh di berbagai wilayah Islam lainnya. Bahkan, dalam perspektif sejarah, dapat dipahami bahwa madrasah itu merupakan hasil evolusi dari masjid sebagai lembaga pendidikan dan khan sebagai tempat tinggal mahasiswa. ${ }^{13}$ Di antara madrasah-madrasah paling terkenal di awal-awal keberadaannya dalam peradaban Islam adalah madrasah Nizamiyah yang didirikan pada tahun 457 H/1065 M, madrasah Nuruddin Zinki, madrasah al-Mustansiriyah didirikan di Bagdad pada tahun 631 H/1234 M, madrasah Nuriyah yang didirikan di Damaskus tahun 563 H/1167 M dan sejumlah madrasah lainnya. ${ }^{14}$

Untuk konteks Indonesia, jika didasarkan pada peraturan Menteri Agama Nomor 2 tahun 1960, maka dapat dipahami bahwa madrasah itu diartikan sebagai tempat pendidikan yang memberi pendidikan, pengajaran dimana

13 Hasan Asari, Menyingkap Zaman Keemasan Islam (Bandung: Citapustaka Media, 2007), h. 73.

${ }^{14}$ Daulay, Sejarah Pertumbuhan, h. 100. ilmu agama sebagai materi yang pokok dalam sistem pengajarannya. Sementara jika merujuk kepada SKB 3 Menteri tahun 1975, maka madrasah itu diartikan sebagai lembaga dimana mata pelajaran agama Islam merupakan materi dasar yang wajib diberikan minimal $30 \%$, sementara mata pelajaran umum diajarkan dalam porsi sebesar $70 \% .^{15}$

Dalam perkembangannya, madrasah muncul sebagai nomenklatur pendidikan Islam modern di Indonesia. Dalam pengertian ini, maka madrasah dapat dipahami sebagai lembaga pendidikan Islam yang berupaya untuk memadukan antara ilmu-ilmu agama atau keislaman dengan ilmu-ilmu umum. ${ }^{16}$

Selanjutnya, sesuai dengan PP No. 29 Madrasah Aliyah kemudian dibagi lagi menjadi dua, yaitu Madrasah Aliyah yang sama dengan SMU (Sekolah Menengah Umum) yang berciri khas Islam, dan Madrasah Aliyah Keagamaan (MAK). Madrasah jenis kedua ini diperuntukkan sesuai dengan maksud yang tertera pada PP No. 29 Tahun 1990

${ }^{15}$ Ibid., h. 125.

${ }^{16}$ Arif Subhan, Lembaga Pendidikan Islam di Indonesia Abad Ke-20: Pergumulan Antara Modernisasi dan Identitas (Jakarta: Kencana, 2012), h. 116. 
Bab I, Pasal 1, ayat 4 yang menegaskan MAK sebagai pendidikan menengah yang mengutamakan penguasaan pengetahuan khusus siswa tentang ajaran agama yang bersangkutan. ${ }^{17}$

Sejalan dengan pasal tersebut, dipertegas lagi di dalam pasal 30 ayat 2 , yang menyatakan bahwa pendidikan keagamaan termasuk madrasah di dalamnya berfungsi untuk mempersiapkan peserta didik menjadi anggota masyarakat yang memahami dan mengamalkan nilai-nilai ajaran agamanya dan menjadi ahli ilmu agama. ${ }^{18}$ Karenanya, pada pasal 30 ayat 3 dikemukakan bahwa pendidikan keagamaan dapat diselenggarakan pada jalur pendidikan formal, nonformal, dan informal; di mana ayat 4 berbunyi bahwa "pendidikan keagamaan itu berbentuk pendidikan diniyah, pesantren, pasraman, pabhaja samanera, dan bentuk lain yang sejenis". 19

Dalam hal ini, pendidikan agama merupakan tanggung jawab bersama antara pemerintah dan masyarakat. Di

${ }^{17}$ Daulay, Pendidikan Islam, h. 59.

18 Hasbullah, Otonomi Pendidikan: Kebijakan Otonomi Daerah dan Implikasinya terhadap Penyelenggaraan Pendidikan(Jakarta: Rajawali Pers, 2010), h. 156 .

${ }^{19}$ Arifin, Memahami Paradigma, h. 47. samping sekolah/madrasah formal yang didirikan oleh pemerintah seperti MIN, MTsN, maupun MAN, masyarakat dapat juga menyelenggarakan pendidikan agama, baik formal (pesantren, madrasah), nonformal (taman pendidikan Alquran (TPA), majlis taklim) maupun informal (madrasah diniyah).

Di awal-awal keberadaannya, sesungguhnya madrasah dalam peradaban Islam dikenal sebagai tempat mempelajari berbagai ilmu secara integratif, termasuk dengan menjadikan karya-karya ulama klasik sebagai bahan kajian. Dalam konteks ini, madrasah pada awalnya adalah jenis lembaga pendidikan yang sangat dominan mengajarkan ilmu-ilmu agama. Seperti telah dikemukakan di atas bahwa di antara madrasah-madrasah paling terkenal di awal-awal keberadaannya dalam peradaban Islam adalah madrasah Nizamiyah yang didirikan pada tahun 457 H/1065 M, Madrasah Nuruddin Zinki, Madrasah al-Mustansiriyah didirikan di Bagdad pada tahun 631 H/1234 M, Madrasah Nuriyah yang didirikan di Damaskus tahun 563 H/1167 $\mathrm{M}$ dan sejumlah madrasah lainnya. 
ISSN 1979-9950 (print) || ISSN 2598-0033 (online), http://jurnal.umsu.ac.id/index.php/intiqad

DOI: 10.30596/intiqad.v\%vi\%i.3752

Vol. 11, No. 2 (Desember 2019)

Pada madrsah-madrasah tersebut di atas diajarkan ilmu-ilmu 'aqliyah, lisâniyah termasuk yang paling utama adalah ilmu-ilmu naqliyah. Ilmu-ilmu naqliyah yang diajarkan di madrasahmadrasah tersebut dipahami sebagai ilmu-ilmu yang bersumber dari Alquran dan al-Hadis seperti; Tafsîr, Hadîs, Fiqih, Tauhîd, tașawuf dan sebagainya, ${ }^{20}$ yang dalam tradisi pendidikan Islam Indonesia dikenal dengan ilmu-ilmu yang tertuang dalam kitab-kitab kuning.

Di awal-awal kehadirannya, madrasah sangat identik dengan kajian ilmu-ilmu agama. Karenanya, dalam dinamika pendidikan Islam di Indonesia, bahwa kitab kuning bukan hanya milik pesantren akan tetapi sudah berkembang di lembaga-lembaga pendidikan lainnya seperti madrasah, bahkan di tengahtengah masyarakat dalam bentuk pengajian-pengajian yang bersifat nonformal. Lahirnya madrasah di Sumatera Barat turut merubah pendidikan Isam di Indonesia yang mencoba memadukan ilmu-ilmu agama dengan tradisi kitab kuning dengan sistem modern. Jika sebelumnya, persepsi masyarakat bahwa kitab kuning hanya merupakan suatu kesatuan dengan

${ }^{20}$ Daulay, Sejarah Pertumbuhan, h. 100. pendidikan pesantren saja dan merupakan dominasi pesantren, namun belakangan kitab kuning kini telah menjadi populer juga di di sekolahsekolah modern di Sumatera Barat, seperti Adabiyah School dan Sumatera Thawalib yang berdiri pada Tahun $1910 .{ }^{21}$

Dalam perkembangannya di Indonesia, madrasah dipandang sebagai "jalan tengah alternatif" yang menjembatani kesenjangan antara sekolah-sekolah umum dan pendidikan tradisional pesantren. Pada madrasahmadrasah modern seperti ini, tertanam semangat yang kuat untuk melakukan reformasi masyarakat dengan jalan kembali kepada sumber-sumber asli Islam yang menjadikannya sebagai suatu perwujudan

reformisme Islam. ${ }^{22}$ Ditegaskan oleh Yudi Latif bahwa karena kemampuan madrasah dalam memadukan antara kurikulum agama dan umum tersebut, maka madrasah dikenal berfungsi sebagai

${ }^{21}$ Hasbullah, Sejarah Pendidikan Islam di Indonesia: Lintasan Sejarah Pertumbuhan dan Perkembangan (Jakarta: RajaGrafindo Persada, 1999), h. 160.

${ }^{22}$ Subhan, Lembaga Pendidikan, h. 117. 
tempat reproduksi ulama-intelek, sebuah istilah yang muncul belakangan. ${ }^{23}$

Meskipun berbeda dengan pesantren, namun di awal-awal pertumbuhannya, madrasah masih memegang teguh tradisi pembelajaran kitab kuning walaupun tidak sekuat yang terdapat di pesantren. Sebelum diberlakukannya berbagai peraturan oleh Pemerintah, terutama SKB Tiga Menteri, madrasah-madrasah yang didirkikan oleh organisasi-organisasi masyarakat seperti Al-Irsyad， Perhimpunan Umat Islam (PUI), Al Washliyah, Muhammadiyah, NU dan lain-lain masih mengajarkan kitab-kitab kuning di dalam kurikulumnya. Pada umumnya madrasah pada saat itu, baik yang didirikan oleh perorangan maupun organisasi masih menggunakan kurikulum yang tidak seragam. Masing-masing memiliki kurikulumnya tersendiri. Sehingga dapat diketahui bahwa perbandingan antara bobot mata pelajaran agama dengan mata pelajaran umum di madrasahmadrasah itu rekatif berbeda antara satu madrasah dengan yang lainnya, dimana ada sebagian yang mencantumkan

${ }^{23}$ Yudi Latif, Intelegensia Muslim dan Kuasa, Geneologi Intelegensia Muslim Abad Ke20 (Bandung: Mizan, 2005), h. 138-139. perbandingan $30: 70, \quad 40: 60, \quad 50: 50$, $60: 40$, dan $70: 30 .^{24}$

\section{Metode dan Pendekatan Penelitian}

Penelitian ini menggunakan metode kualitatif, yakni metode yang dimaksudkan untuk menggali data secara mendalam, dan bahkan sampai pada upaya menggali makna di balik data, tentunya terkait dengan data resistansi tradisi kitab kuning pada madrasah $\mathrm{Al}$ Washliyah di Sumatera Utara. ${ }^{25}$ Dalam penelitian kualitatif, data yang dikumpulkan bukan angka-angka, melainkan berupa kata-kata atau gambaran. Data yang dimaksud berasal dari wawancara, observasi, catatan lapangan, video tape, dokumen pribadi dan dokumen-dokumen lainnya. ${ }^{26}$ Dalam penelitian ini, peneliti merupakan instrumen kunci, sebab penelitian kualitatif merupakan pendekatan yang menekankan pada hasil pengamatan peneliti, sehingga manusia sebagai instrumen penelitian menjadi suatu

\footnotetext{
${ }^{24}$ Daulay, Sejarah Pertumbuhan, h. 104.

25 Sugiyono, Metode Penelitian
} Kuantitatif, Kualitatif, dan $R \& D$ (Bandung: Alfabeta, 2008), h. 15.

26 Lexy J. Moleong, Metodologi Penelitian Kualitatif (Bandung: Remaja Rosda Karya, 2005), h. 11. 
ISSN 1979-9950 (print) || ISSN 2598-0033 (online), http://jurnal.umsu.ac.id/index.php/intiqad

DOI: 10.30596/intiqad.v\%vi\%i.3752

Vol. 11, No. 2 (Desember 2019)

keharusan. ${ }^{27}$ Bahkan dalam penelitian kualitatif, posisi peneliti menjadi instrumen kunci (the key instrument). ${ }^{28}$

Dari segi pendekatan, penelitian ini menggunakan pendekatan field research (penelitian lapangan) yang bersifat deskriptif. Moleong menyatakan bahwa field research dianggap sebagai pendekatan luas dalam penelitian kualitatif. Ide pentingnya adalah bahwa peneliti berangkat ke 'lapangan' untuk mengadakan pengamatan tentang suatu fenomena dalam suatu keadaan alamiah atau 'in situ'. Dalam hal demikian, maka pendekatan ini terkait erat dengan pengamatan-berperanserta. Dengan pendekatan ini, peneliti lapangan biasanya membuat catatan lapangan secara ekstensif yang kemudian dibuatkan kodenya dan dianalisis dalam berbagai cara. $^{29}$

Oleh karena itu, dalam penelitian ini, peneliti ingin menggambarkan secara utuh dan mengungkapkan serta menganalisa fakta-fakta yang terkait dengan upaya resistansi tradisi kitab kuning pada madrasah-madrasah $\mathrm{Al}$

27 Noeng Muhajir, Metode Penelitian Kualitatif (Yogjakarta: Rake Sarasin, 2003), h. 27

${ }^{28}$ Sugiyono, Metode Penelitian, h. 223.

${ }^{29}$ Moleong, Metodologi Penelitian, h. 26.
Washliyah yang terdapat di Sumatera Utara.

\section{Hasil Analisis dan Pembahasan}

1. Dasar-dasar Epistemologis

\section{Resistansi Tradisi Kitab Kuning}

\section{a. Keutamaan Ilmu Agama}

Sebagian pihak memang tidak sepakat dengan kesimpulan bahwa alGhazâlî telah menginspirasi umat untuk berpikir bahwa ilmu-ilmu agama itu lebih mulia dari ilmu lainnya yang kemudian memunculkan sikap pengabaian terhadap ilmu-ilmu lainnya (umum). Mereka berpandangan bahwa al-Ghazâlî hanya melakukan pengklasifikasian, bukan memberikan pembedaan derajad kemuliaan ilmu. Sehubungan dengan hal itu, Hasan Asari menegaskan bahwa meski beberapa ilmuwan muslim sebelumnya telah menghasilkan berbagai klasifikasi ilmu pengetahuan, namun yang membedakan mereka dengan klasifikasi yang dilakukan oleh al-Ghazâlî adalah karena adanya penekanan pertimbangan religious dan moral ketimbang sekedar daftar atau indeks semata. ${ }^{30}$ Karenanya, dengan adanya penekanan moral dalam

${ }^{30}$ Hasan Asari, Nukilan Pemikiran Islam Klasik: Gagasan Pendidikan Abu Hamid AlGhazâlî (Medan: IAIN Press, 2012), h. 93. 
INTIQAD: JURNAL AGAMA DAN PENDIDIKAN ISLAM

ISSN 1979-9950 (print) || ISSN 2598-0033 (online), http://jurnal.umsu.ac.id/index.php/intiqad

DOI: 10.30596/intiqad.v\%vi\%i.3752

Vol. 11, No. 2 (Desember 2019)

bentuk pembedaan kemuliaan dan anjuran prioritas mempelajari satu disiplin ilmu dibanding disiplin ilmu yang lain dalam klasifikasi al-Ghazâlî ini lah menurut penulis yang secara tidak langsung telah memengaruhi cara pandang sebagian umat Islam yang memandang bahwa ilmu-ilmu agama sebagai ilmu yang lebih utama dan harus diutamakan sebagaimana yang dipahami oleh madrasah-madrasah Al Washliyah. Cara pandang yang demikian dengan sendirinya memunculkan sikap abai terhadap pengembangan ilmu-ilmu laiannya sebagaimana terlihat dalam praktik pendidikan pesantren.

Sehubungan dengan itu hasil penelitian menunjukkan bahwa salah satu alasan yang mendasari upaya mempertahankan tradisi pembelajaran kitab kuning di madrasah-madrasah $\mathrm{Al}$ Washliyah adalah terkait dengan cara pandang mereka yang meyakini adanya kemuliaan atau keutamaan ilmu-ilmu agama dibanding dengan ilmu-ilmu lainnya (umum). Sistem pendidikan yang dijalankan di madrasah-madrasah $\mathrm{Al}$ Washliyah lebih mengutamakan pendalaman ilmu-ilmu agama, sementara ilmu-ilmu umum dipandang hanya sebagai pelengkap atau sekedar pemenuhan tuntutan zaman dan peraturan saja. Karenanya, ciri khas yang ingin ditonjolkan pada diri siswasiswanya adalah penguasaan ilmu-ilmu agama.

\section{b. Kriteria Ulama}

Sala satu kriteria utama seorang ulama bagi guru-guru madrasah $\mathrm{Al}$ Washliyah adalah kemampuan membaca kitab kuning. Tidak bisa dikategorikan sebagai ulama, bahkan tidak bisa dipandang sebagai ustaz yang berkualitas jika tidak mampu mengakses kitab kuning, sementara tujuan utama pendidikan madrasah Al Washliyah adalah menghasilkan ulama, minimal menjadi ustaz. Terkait dengan kriteria ulama, para ahli telah memberikan defenisi yang beragam tentang ulama dan kriteria ulama itu sendiri. Said Quțub misalnya menjelaskan defenisi ulama sebagai berikut:

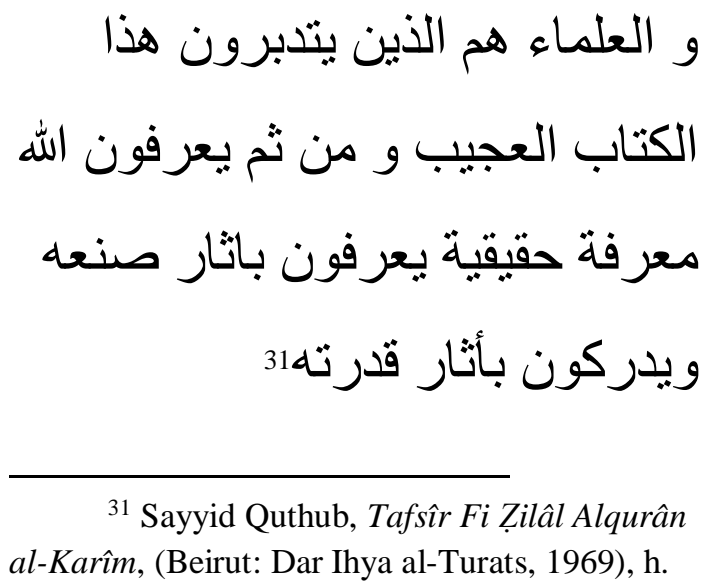

${ }^{31}$ Sayyid Quthub, Tafsîr Fi Zilâl Alqurân al-Karîm, (Beirut: Dar Ihya al-Turats, 1969), h. 
INTIQAD: JURNAL AGAMA DAN PENDIDIKAN ISLAM

ISSN 1979-9950 (print) || ISSN 2598-0033 (online), http://jurnal.umsu.ac.id/index.php/intiqad

DOI: 10.30596/intiqad.v\%vi\%i.3752

Vol. 11, No. 2 (Desember 2019)
Ulama itu adalah mereka yang meneliti dan memahami kitab Alquran, dari situ ia mengetahui Allah dengan sebenar-benarnya, mengetahui pengaruh ciptaanNya dan kekuasaanNya.

Sementara itu, imam Sufyan asŚawri di dalam tafsir Ibnu Kasîr menjelaskan kriteria ulama sebagai berikut:

$$
\begin{aligned}
& \text { العلماء ثلاثثة : عالم بالله و بأمر الله, } \\
& \text { عالم بالله ليس بعالم بأمر الله, عالم } \\
& \text { بأمر الله و لبس بعالم بالله. فا العالم } \\
& \text { بالله و بأمر الله الذي بخثي الله و } \\
& \text { يعلم الحدود و الفرائض32 }
\end{aligned}
$$

Ulama itu ada tiga macam: (a) Alim (orang yang kenal) dengan Allah dan tahu tentang perintahNya; (b) Orang yang kenal dengan Allah tapi tidak tahu tentang perintah-perintahNya; (c) Orang yang tahu dengan perintah-perintah Allah akan tetapi tidak tahu dengan Allah. Adapun orang yang kenal dengan Allah dan kenal dengan perintahperintahNya adalah mereka yang takut kepada Allah dan mengetahui aturanatura dan kewajiban-kewajiban.

32 Abu al-Fida' Ismail Ibn Katsir, Tafsîr Alqur'ân al-'Azîm (Beirut: Dar al-Ma'rifah, 1989), h. h.554.
Definisi dan kriteria di atas menunjukkan bahwa ulama itu berkaitan erat dengan pengetahuan ilmu agama. Sehubungan dengan itu, bagi guru-guru madrasah Al Washliyah, seseorang yang bisa disebut ulama adalah mereka yang pandai membaca dan memahami kitabkitab kuning dan terbiasa menjadikan kitab kuning sebagai bahan pengajian dan rujukan utama dalam menyampaikan pengajian-pengajian atau ceramah. Karenanya, sebagaimana dalam penelitian Muhammad Rozali menunjukkan bahwa ulama-ulama $\mathrm{Al}$ Washliyah itu digolongkan pada dua model, yaitu ulama dengan tipologi yang berpikiran lebih moderat, yaitu biasanya dari kalangan ulama-ulama Al Washliyah yang pernah belajar di luar negeri (Haramain) seperti Hasan Maksum (1884-1936), dan tipologi ulama yang benar-benar berupaya mempertahankan ketradisionalannya di dalam menjawab berbagai permasalahan yang ada di tengah masyarakat (dengan berpegang teguh pada rujukan kitab kuning), yakni ulama-ulama $\mathrm{Al}$ Washliyah yang hanya belajar di dalam negeri yakni di Maktab Islamiyah Tapanuli dan Maktab al-Hasaniyah seperti Abdurrahman Syihab (1910- 
ISSN 1979-9950 (print) || ISSN 2598-0033 (online), http://jurnal.umsu.ac.id/index.php/intiqad

DOI: 10.30596/intiqad.v\%vi\%i.3752

Vol. 11, No. 2 (Desember 2019)

1955) dan Muhammad Arsyad Thalib Lubis (1908-1972). ${ }^{33}$

\section{c. Keyakinan Pada Hasil Ijtihad Ulama Terdahulu}

Salah satu keyakinan yang masih dipegang teguh oleh guru atau warga madrasah Al Washliyah adalah bahwa secara empirik saat ini belum ada di antara umat ini yang mampu melakukan ijtihad, disebabkan begitu banyaknya syarat yang harus dipenuhi oleh seseorang agar layak berijtihad. ${ }^{34} \mathrm{Al}$ Jurjâni misalnya menyebutkan bahwa seorang mujtahid haruslah orang yang mengetahui Alquran beserta maknamaknanya, mengetahui sunnah dengan mengetahui jalur-jalur periwayatannya, redaksi-redaksinya (matan), dan maknamaknanya. Dia juga harus mampu tepat dalam menggunakan qiyas serta memahami betul kebiasaan-kebiasaan ('urf) manusia. ${ }^{35}$

Bahkan menurut mereka, bahwa ulama-ulama yang dipandang besar dan

\footnotetext{
${ }^{33}$ Muhammad Rozali, Tradisi Keulamaan Al Jam'iyatul Washliyah Sumatera Utara (Yogyakarta: LKiS, 2017), h. 94.

34 'Iyadh bin Nami Sulami, Uș̂ul al-Fiqh allazi Lâ Yasa' al-Faqîh Jahlahu (Riyadh: Dâr at-Tadmuriyyah, 1426/2005), h. 455-456.

35 Abi Hasan Ali Bin Muhammad bin Ali al-Husainy al-Jurjâni, At-Ta'rîfât (Beirut: Dâr alKutub 'Ilmiyyah, 1434), h. 203.
}

terkenal di dunia saat ini seperti ulama Syiria Said Ramaḍan al-Bûțî dalam beragama pun masih muqallid, mengikut kepada imam-imam mazhab atau pun kepada ulama tabi'in. Begitu juga dengan syaikh Wahbah al-Zuhaili sendiri pun masih muqallid, apalagi lah ulamaulama sekelas Indonesia saat ini. ${ }^{36}$

Ketidakmampuan berijtihad itu lah kemudian menurut mereka yang dengan sendirinya mengharuskan umat Islam bertaqlid kepada ulama-ulama terdahulu, khususnya para ulama imam mazhab seperti imam Hanafi, imam Maliki, imam Syafi'i, imam Ahmad/Hambali atau ulama-ulama penerus yang belajar kepada mereka. Sebagaimana diketahui bahwa imam-imam mazhab tersebut melakukan ijtihad dan hasil-hasil ijtihad mereka itu kemudian dituangkan di dalam kitab, begitu juga dengan ulamaulama penerus yang merupakan muridmurid mereka juga menuliskan kitabkitab yang tentunya semuanya berbahasa Arab, atau yang lebih popular dikenal dengan kitab kuning. Di sinilah letak logika yang dipegang oleh guru-guru madrasah Al Washliyah bahwa umat ini

Muhyiddin Masykur, Guru Mata
Pelajaran Fiqih Madrasah Tsanawiyah
Muallimin UNIVA Medan, Wawancara di Medan
pada tanggal 07 Desember 2018.


ISSN 1979-9950 (print) || ISSN 2598-0033 (online), http://jurnal.umsu.ac.id/index.php/intiqad

DOI: 10.30596/intiqad.v\%vi\%i.3752

Vol. 11, No. 2 (Desember 2019)

harus betul-betul diajari agar mampu membaca kitab-kitab kuning, karena kapasitas mereka yang hanya bisa taqlid kepada hasil ijtihad atau tafsiran ualamulama di mana itu semua tertuang di dalam kitab-kitab berbahasa Arab atau yang lebih dikenal dengan kitab kuning. Karenanya, untuk bisa bertaqlid, maka modal yang harus dimiliki adalah kemampuan membaca dan mengkaji kitab-kitab mereka untuk diamalkan dalam kehidupan beragama dan disampaikan kepada umat yang lain. ${ }^{37}$

Paradigma yang dipakai oleh warga madrasah Al Washliyah dalam menyikapi kitab kuning ini tampaknya lebih mirip dengan paradigma yang dipakai oleh masyarakat tradisional. Meskipun bagi kaum modern, paradigma seperti ini sebenarnya dipandang terlalu ekstrim dan kurang menguntungkan kaum muslimin, sebab dalam pandangan kaum ini, kepengikutan mutlak terhadap tafsiran para ulama mazhab itu sama halnya mengekang kemungkinan pengembangan pemikiran Islam khusunya pada wilayah ajaran yang bersifat z̧annî. Terkait hal ini, Syafi'i

\footnotetext{
37 Muhyiddin Masykur, Guru Mata Pelajaran Fiqih Madrasah Tsanawiyah Muallimin UNIVA Medan, Wawancara di Medan pada tanggal 07 Desember 2018.
}

Ma'arif menyatakan dengan tegas bahwa pemikiran pembaharuan Islam itu mungkin dan harus dilakukan di atas dasar kemakluman akan adanya hal-hal yang absolut dan nisbi, yang qat' 'îy dan zannî dalam sistem ajaran Islam. Karenanya pembaharuan Islam itu didorong oleh dan hanya menyentuh bagian yang relativ, nisbi, atau yang zannî dari ajaran Islam itu sendiri. ${ }^{38}$

\section{d. Konsekuensi Kepengikutan \\ Paham Ahl as-Sunnah wa al- Jamâ'ah dan Mazhab Syafi'i.}

Salah satu tradisi keulamaan Al Washliyah sejak awal adalah peneguhan ajaran agama sesuai dengan tradisi Sunni di Nusantara, sehingga mempertahankan pengajaran kitab kuning menjadi suatu kemestian yang tidak bisa ditawar. Logika yang digunakan oleh guru-guru madrasah Al Washliyah adalah bahwa ketika organisasi ini telah menetapkan keharusan mengikuti Ahl as-Sunnah wa al-Jamâ'ah, maupun mazhab Syafi'i dalam fiqih bagi seluruh warganya, maka kepengikutan itu hanya akan bisa terwujud dengan benar, jika mereka

38 Hasan Asari, Modernisasi Islam: Tokoh, Gagasan, dan Gerakan (Bandung: Citapustaka Media, 2007), h. 5. 
(warga Al Washliyah) itu bisa mengakses ajaran-ajaran para ulama yang ada dalam aliran dan mazhab itu, yang notabenenya ajaran-ajaran itu tertuang dalam kitab yang berbahasa Arab, yang dikenal dengan sebutan kitab kuning.

Mengiktui ahl al-Sunnah wa alJamâ'ah bagi guru-guru Al Washliyah adalah artinya mengikuti paham aqidah sebagaimana yang dipahami dan diajarkan di kalangan ulama-ulama Asy'ariyah dan Maturidiyah. ${ }^{39}$ Kepengikutan yang demikian terbukti bahwa kitab-kitab tauhid yang dipelajari dan diajarkan di lingkungan Al Washliyah adalah kitab yang sejalan dengan paham Asy'ariyah maupun Maturidiyah, seperti kitab Tuhfah al-Murîd alâ Jauharah al-Tauhîd karya Syaikh al-Baijûrî, dan penekanan untuk mengikuti paham itu sangat kuat dilakukan oleh para guru. Kuatnya penekanan untuk mengikuti paham ini misalnya dapat penulis rasakan langsung di dalam pengajian hari Minggu yang dilaksanakan di masjid Univa Medan. Sebagai misal, pada saat membahas

39 Abdul Aziz, Guru Mata Pelajaran Tauhid Madrasah Tsnawiyah Muallimin Al Washliyah UNIVA Medan, Wawancara di Medan pada tanggal 25 September 2019. persoalan apakah surga itu telah diciptakan sejak lama atau belum ada saat ini dan baru akan diciptakan setelah hari kiamat. Ustaz Muhyiddin Masykur, sebagai pemateri pengajian membacakan apa yang tertuang di dalam kitab Jauharah al Tauhîd itu, dimana keyakinan ulama-ulama Ahl al-Sunnah wa al-Jamâ'ah adalah bahwa, baik surga maupun neraka, keduanya diyakini telah sama-sama diciptakan sejak lama, sementara sebagian filosof maupun kalangan ulama Muktazilah seperti Abi Hâsim dan Abdul Jabbâr mengingkari keyakinan yang demikian, dan ulama Muktazilah ini menegaskan bahwa surga itu baru diciptakan hanya setelah hari kiamat kelak. Padda saat memberikan penjelasan terkait hal itu, tampak bahwa muallim Muhyiddin Masykur demikian tegas mengatakan bahwa keyakinan yang harus kita pegang adalah sebagaimana yang ditegaskan oleh pengarang kitab ini, bahwa surga dan neraka itu telah diciptakan sejak lama, bukan sebagaimana yang diingkari oleh para filosof maupun pandangan ulama kalangan Muktazilah, bahwa keduanya kan diciptakan setelah hari kiamat tiba. 


\section{e. Kitab Kuning Sebagai Sibghah} (Ciri Khas) Al Washliyah

Dalam pandangan guru-guru madrasah Al Washliyah, kitab kuning merupakan ciri khas yang sejak dulu telah melekat pada diri warga maupun lembaga pendidikan Al Washliyah. Kitab kuning dipandang sebagai refrensi pengamalan agama yang paripurna. Bahkan transmisi dan pengkajian kitab kuning dijadikan sebagai prioritas utama sehingga ia dipandang merupakan ciri khas pembelajaran di lingkungan madrasah-madrasah Al Washliyah, dan bahkan dipandang sebagai salah satu syarat utama bagi pertahanan eksistensi dan kemajuan madrasah-madrasah $\mathrm{Al}$ Washliyah di masa depan.

Sedemikian melekatnya kitab kuning dengan pendidikan $\mathrm{Al}$ Washliyah, maka setiap siswa yang tamat dari madrasah $\mathrm{Al}$ Washliyah akan merasa gamang dalam bersosialisasi di masyarakat, jika tidak bisa menguasai atau mengetahui cara membaca kitab kuning dengan baik, sebab bagi masyarakat, kemampuan membaca kitab kuning itu sudah dipandang sebagai ciri khas yang melekat pada diri alumnialumni madrasah Al Washliyah. ${ }^{40}$

Sebelum munculnya SKB 3 Menteri, madrasah-madrasah yang berada di bawah asuhan organisasiorganisasi Islam, termasuk madrasah di bawah naungan Al Washliyah memang masih sangat kental dengan tradisi kitab kuning. Hal itu sebagaimana dikemukakan oleh Haidar Putra Daulay, meskiupun berbeda dengan pesantren, namun di awal-awal pertumbuhannya, madrasah menurutnya masih memegang teguh tradisi pembelajaran kitab kuning. Sebelum diberlakukannya berbagai peraturan oleh Pemerintah, terutama SKB 3 Menteri, madrasah-madrasah yang didirikan oleh organisasi-organisasi masyarakat seperti Al-Irsyad, Perhimpunan Umat Islam (PUI), Al Washliyah, Muhammadiyah, NU dan lain-lain masih mengajarkan kitab-kitab kuning di dalam kurikulumnya. Kurikulum di madrasah-madrasah tersebut, baik yang didirikan oleh organisasi maupun pribadi belum ada keseragaman. Dalam perbandingan antara bobot mata pelajaran agama dan umum juga masih berbeda antara satu madrasah dengan madrasah lainnya, ada

${ }^{40}$ Rozali, Tradisi Keulamaan, h. 83. 
INTIQAD: JURNAL AGAMA DAN PENDIDIKAN ISLAM

ISSN 1979-9950 (print) || ISSN 2598-0033 (online), http://jurnal.umsu.ac.id/index.php/intiqad

DOI: 10.30596/intiqad.v\%vi\%i.3752

Vol. 11, No. 2 (Desember 2019)

yang mencantumkan perbandingan $30: 70,40: 60,50: 50,60: 40$, dan 70:30. ${ }^{41}$

Karena dipandang sebagai suatu ciri khas madrasah, maka salah satu alasan utama bagi madrasah-madrasah Al Washliyah untuk tetap berupaya mempertahankan tradisi pembelajaran kitab kuning itu adalah dalam rangka mempertahankan citranya sebagai lembaga pendidikan Islam yang berciri khas kitab kuning, dimana siswa dan alumni-alumninya dikenal dengan kemampuan membaca kitab kuning yang baik di tengah masyarakat. Hal ini sebagaimana ditegaskan sebagai berikut:

Salah satu alasan utama mengapa kita masih terus mempertahankan mengajarkan kitab-kitab kuning, atau ilmu-ilmu alat yang memungkinkan siswa pandai membaca kitab kuning adalah karena kitab kuning itu merupakan ciri khas utama kita sejak dulu. Masyarakat masih mau memasukkan anak-anaknya di madrasah kita justru yang paling utama dikejar mereka adalah kitab kuning itu. Mereka memasukkan anaknya di madrasah ini supaya ilmu agamanya bagus, sementara untuk bisa memiliki ilmu agama yang bagus, tentunya mereka harus bisa

\footnotetext{
${ }^{41}$ Daulay, Sejarah Pertumbuhan, h. 104
}

membaca kitab-kitab kuning, karena di situlah termuat ilmu agama yang masih asli itu. Jadi, kita bertahan seperti ini tujuannya untuk mempertahankan ciri khas kita, kita tidak mau mengkhianati apa yang sudah digariskan oleh pendahulu kita, meskipun saat ini mungkin kadar dan kualitasnya sedikit menurun, tapi kita tetap berusaha untuk mempertahankannya". 42

\section{f. Bahasa Arab Sebagai Bahasa Utama Ilmu Agama}

Dalam berbagai teori dijelaskan kaitan erat antara bahasa dengan ilmu pengetahuan dimana bahasa merupakan sarana penting dalam pengembangan ilmu pengetahuan. Demikian halnya dengan bahasa Arab tentu merupakan sarana penting ilmu pengetahuan, terutama ilmu pengetahuan agama.

Terkait dengan hal itu, menarik untuk dikemukakaan tentang fakta sejarah pada tahun 1938-an, yang menunjukkan adanya suatu perdebatan tentang siapakah sebenarnya yang paling layak disebut sebagai kaum inteligensia, dalam kaitannya dengan penguasaan

42 Muhammad Arifin, Guru Mata Pelajaran Tafsir Madrasah Aliyah Muallimin UNIVA Medan, Wawancara di Medan pada tanggal 07 Desember 2018. 
ISSN 1979-9950 (print) || ISSN 2598-0033 (online), http://jurnal.umsu.ac.id/index.php/intiqad

DOI: 10.30596/intiqad.v\%vi\%i.3752

Vol. 11, No. 2 (Desember 2019)

bahasa. Perdebatan itu bahkan telah memunculkan dua golongan inteligensia di Indonesia pada saat itu, yaitu golongan inteligensia pertama adalah mereka yang menguasai bahasa Belanda, sementara golongan inteligensia lainnya adalah mereka yang menguasai bahasa Arab.

Lebih jauh ke belakang, hubungan erat antara penguasaan bahasa dengan pengembangan ilmu itu juga terlihat dalam fakta historis bahwa fungsi utama perpustakaan di masa kejayaan Islam adalah fungsi penerjemahan. Di samping fungsi pengajaran, perpustakaanperpustakaan yang tumbuh pada masa kejayaan itu juga berfungsi sebagai tempat penerjemahan karya-karya ilmiah, baik yang bersumber dari Yunani, Suryani, Qibți, maupun Persia. Bahkan penerjemah merupakan salah satu di antara 5 (lima) fungsionaris perpustakaan pada masa itu yang bertugas menerjemahkan karya-karya yang dianggap perlu diterjemahkan. ${ }^{43}$ Sebagaimana yang dikemukakan oleh Hasan Asari bahwa para penerjemah ini bertugas

43 Hasan Asari, Sejarah Pendidikan Islam: Membangun Relevansi Masa Lalu dengan Masa Kini dan Masa Depan (Medan: Perdana Publishing, 2018), h. 42. menerjemahkan buku-buku yang berbahasa asing ke dalam bahasa Arab. Bahkan posisi penerjemah ini sangat signifikan, terutama pada awal-awal tumbuhnya lembaga perpustakaan di masa kejayaan Islam. ${ }^{44}$

\section{Latar Belakang Sosial-Religius}

\section{Resistansi Tradisi Kitab Kuning}

a. Pendangkalan Pembelajaran

\section{Ilmu Agama}

Salah satu faktor yang melatar belakangi kuatnya usaha untuk mempertahankan tradisi pembelajaran kitab kuning di madrasah-madrasah Al Washliyah adalah karena anggapan adanya upaya pendangkalan pembelajaran atau materi ilmu agama di dunia pendidikan oleh pihak Pemerintah yang dalam hal ini adalah Departemen Agama.

Bagi madrasah Al Washliyah, pemberlakuan kurikulum SKB 3 Menteri itu pada dasarnya adalah merupakan pendangkalan terhadap kualitas dan kuantitas pengajaran ilmu agama.

Bagi madrasah Al Washliyah, materi-materi ilmu agama sebagaimana

${ }^{44}$ Hasan Asari, Menyingkap Zaman Keemasan Islam, (Bandung: Citapustaka Media, 2007), h. 207. 
yang termuat di dalam buku-buku paket mata pelajaran kurikulum SKB 3 Menteri itu sama sekali tidak cukup membekali anak-anak dalam pengamalan agama dengan baik. Hal ini sebagaimana ditegaskan oleh Muhayyan sebagai berikut:

Materi yang diajarkan di dalam buku-buku paket seperti Quran Hadits, Aqidah Akhlak, dan Fiqih itu bisa dikatakan sangat dangkal, terutama jika dibandingkan dengan materi yang selama ini kita ajarkan melalui buku-buku kurikulum diniyah Al Washliyah. Kalau siswa hanya mengandalkan itu, maka boleh jadi nanti banyak pengamalan agama mereka yang tidak sempurna bahkan tidak sah, karena apa yang diajarkan kepada mereka tidak sempurna. Nah, karena itulah maka sebenarnya kita sedih, karena kita pun mau tidak mau harus mengajarkan itu juga, karena itu juga nanti yang akan diujikan. Tapi begitupun kita tetap mengajarkan kitabkitab yang ada, sementara bukubuku paket itu diajarkan hanya sekedar untuk memenuhi kebutuhan saat ujian nanti. ${ }^{45}$

Sebagai dampak dari semakin menjamurnya madrasah-madrasah Tsanawiyah maupun Aliyah yang menggunakan kurikulum SKB 3 Menteri

\footnotetext{
45 Muhayyan, WKM I Madrasah Tsanawiyah Muallimin UNIVA Medan, Wawancara di Medan pada tanggal 12 Desember 2018 .
}

Departemen Agama, maka madrasah ibtidaiyah yang menggunakan kurikulum diniyah pun secara berangsur mulai hilang. Masyarakat atau orang-orang kemudian lebih tertarik memasukkan anak-anak mereka ke Sekolah Dasar Negeri yang porsi pengajaran agamanya sangat terbatas ataupun ke MIN yang kuantitas pengajaran agamanya juga tidak sebanyak yang terdapat di dalam kurikulum diniyah Al Washliyah.

\section{b. Krisis Ulama}

Sebagai dampak dari pendangkalan ilmu agama, maka menurut guru-guru madrasah $\mathrm{Al}$ Washliyah saat ini umat Islam khususnya di kalangan warga Al Washliyah tengah berada dalam kondisi krisis ulama, dimana semakin sulit menemukan ulama yang benar-benar mumpuni keilmuan agamanya misalnya sekelas tuan Arsyad Thalib Lubis, Nukman Sulaiman, dan lainnya. Karenanya, menurut mereka upaya mempertahankan tradisi pembelajaran kitab kuning di madrasah Al Washliyah adalah juga sebagai respons untuk memperbaiki keadaan itu. Jika dulu madrasah-madrasah mampu melahirkan ulama, maka saat ini peran madrasah itu 
ISSN 1979-9950 (print) || ISSN 2598-0033 (online), http://jurnal.umsu.ac.id/index.php/intiqad

DOI: 10.30596/intiqad.v\%vi\%i.3752

Vol. 11, No. 2 (Desember 2019)

sudah melemah karena materi yang diajarkan di madrasah-madrasah semakin lama semakin dangkal terutama pasca penerapan kurikulum SKB 3 Menteri/Departemen Agama. Menurut Jumain, krisis ulama yang terjadi saat ini dapat dilihat dengan jelas baik dari segi kualitas maupun kuantitasnya. Hal itu dijelaskannya sebagai berikut:

Kondisi krisis ulama itu dengan sangat tegas disebutkan oleh Ramli Abdul Wahid-sebagai tokoh pendidikan Al Washliyah memang tengah dialami oleh umat Islam saat ini, dan krisis ulama itu menurut beliau berakar dari perubahan dalam kurikulum dan orientasi lembaga pendidikan Islam termasuk madrasah. Khusus di Sumatera Utara para ulama telah banyak yang kembali ke hadirat Allah sehingga semakin hari semakin terasa semakin langkanya ulama yang dapat dipegang fatwa-fatwanya, seperti ustaz Arifin Isa, Hamdan Abbas, Ustaz H. Fuad Said, Ustaz Tengku Ali Muda, Ustaz Lahmuddin Nasution.

Lebih lanjut Ramli menjelaskan bahwa tujuan madrasah dan pesantren pun saat ini sudah lebih bersifat pragmatis, dimana bukan lagi untuk memproduk ulama yang bisa membaca kitab-kitab berbahasa Arab, melainkan tujuannya adalah untuk memenuhi kebutuhan pasar. Madrasah-madrasah yang ada saat ini menjadikan orientasi utamanya bagaimana agar lulusannya bisa masuk ke perguruan tinggi umum dan setelah itu bisa memperoleh pekerjaan sesuai yang dibtuhkan oleh dunia pasar.

\section{c. Berkembangnya Paham-paham}

\section{Keagamaan}

Sebagai konsekuensi kepengikutan pada paham Ahl al-Sunnah wa alJamâ'ah, maka buku-buku diniyah yang digunakan di madrasah-madrasah $\mathrm{Al}$ Washliyah difokuskan pada buku-buku yang ditulis oleh kalangan ulama Sunni. Mteri yang diajarkan pun difokuskan pada materi-materi aqidah yang sejalan dengan aqidah Ahl al-Sunnah wa alJamâ'ah. Dengan demikian, siswa atau alumni madrasah-madrasah $\mathrm{Al}$ Washliyah dengan sendirinya memiliki pengetahuan dan kepengikutan yang kuat terhadap paham-paham keagamaan yang sejalan dengan Sunni tersebut. Kaitannya dengan resistansi tradisi kitab kuning, bahwa semakin maraknya paham-paham intelektual dan keagamaan yang dipandang menyimpang saat ini, seperti 
sekularisme, liberalisme dan juga aliranaliran keagamaan lainnya, dipandang dapat menjadi ancaman yang serius bagi aqidah umat.

Kekhawatiran yang demikian itu jugalah yang melatar belakangi semakin kuatnya upaya $\mathrm{Al}$ Washliyah melalui madrasah-madrasahnya untuk tetap mempertahankan tradisi pengajaran kitab kuning. Kitab kuning dipandang bisa menjadi bahan kajian yang akan membentengi para siswa darri pemikiran-pemikiran sesat yang berkembang saat ini. Terlebih lagi, kitab kuning yang diajarkan di madrasah $\mathrm{Al}$ Washliyah itu jelas mengikut kepada aliran Ahl al-Sunnah wa al-Jamâ'ah. Bagi mereka di situlah kelemahan jika mengikuti buku-buku mata pelajaran SKB 3 Menteri di mana kepengikutan aqidahnya tidak ditentukan sehingga pada siswa disuguhkan dengan berbagai aneka keyakinan tanpa memberi ketetapan mana di antara yang banyak itu yang harus diikuti. ${ }^{46}$

Salah satu visi yang terkandung dalam pemaduan antara kurikulum Nasional (SKB 3 Menteri) dengan

46 Komisi Fatwa MUI Sumatera Utara, Data Aliran-aliran Menyimpang di Sumatera Utara ( Dokumen tidak diterbitkan), h. 1-3.
Kurikulum Diniyah yang diterapkan di MTs Muallimin UNIVA Medan adalah dalam rangka menghadapi tantangan aliran-aliran sesat. Hal ini ditegaskan dalam latar belakang penetapan visi misinya sebagai berikut: perkembangan dan tantangan masa depan seperti; perkembangan ilmu pengetahuan dan teknologi, globalisasi yang sangat cepat, informasi, dan berubahnya kesadaran masyarakat dan orang tua terhadap pendidikan, demikian juga dengan semakin menjamurnya aliran sesat, semua itu mengharuskan madrasah Tsanawiyah Muallimin UNIVA Medan dengan bijak merespon tantangan sekaligus menyikapi peluang itu. Oleh karena itu, salah satu misi yang ditetapkan adalah mengelola madrasah dengan manajemen modern dan terpadu antara kurikulum Nasional dan Kurikulum Diniyah Al Washliyah. ${ }^{47}$

\section{d. Dampak Negatif Teknologi Internet}

Mempertahakan tradisi pembelajaran kitab-kitab diniyah juga dalam konteks menanggapi dampak

47 Dokumen I Kurikulum Madrasah Tsanawiyah Muallimin UNIVA Medan TP. 2017-2018, h. 13. 
negatif perkembangan teknologi sosial media yang membuat materi-materi agama yang disampaikan oleh para da'i sering keliru, karena hanya mengandalkan internet sebagai refrensi. Mendidik anak-anak dengan kemampuan membaca kitab-kitab kuning dimaksudkan agar mereka tidak menjadi "syekh google", yang ketika mempersiapkan materi ceramah atau materi ajar di sekolah-sekolah hanya bisa mengandalkan informasi-informasi yang ada di media internet atau yang beredar di media sosial baik fecebook, wa, instagram dan lainnya.

Hal ini juga menjadi keresahan tersendiri pada diri ustaz Ishaq Naharuddin. Menurutnya, bahwa perkembangan teknologi internet saat ini telah membuat pengajaran agama semakin dangkal dan sering menyimpang. Teknologi internet menyebabkan sebagian besar ustaz cenderung bersikap isntan dan tidak mau lagi bersusah-susah menggali materi ceramah dari kitab-kitab yang primer. Sebagai akibatnya, menurutnya tidak sedikit di antara penceramah yang menyampaikan penjelasan atau ceramah agama secara asal-asalan tanpa dasar dan refrensi yang kuat.

\section{Bentuk-bentuk Resistansi Tradisi Kitab Kuning.}

\section{a. Menolak Kurikulum SKB 3 Menteri Departemen Agama.}

Dalam bentuknya yang paling ekstrim, upaya mempertahankan tradisi pembelajaran kitab kuning atau kitab diniyah di madrasah Al Washliyah itu dilakukan dengan menolak sepenuhnya $\begin{array}{llll}\text { penerapan } & \text { kurikulum } & \text { SKB } 3\end{array}$ Menteri/Departemen Agama. Disebutkan sebagai penolakan, sebab sebagai organisasi, Al Washliyah sebenarnya telah membuat regulasi atau ketetapan yang mengatur tentang kurikulum yang harus digunakan oleh madrasahmadrasah Al Washliyah, sebagaimana hal itu termuat dalam buku sistem pendidikan Al Washliyah (SPA). Di dalam sistem pendidikan Al Washliyah tersebut dijelaskan bahwa pada tingkat SD, SLTP, SMU, dan SMK, Al Washliyah harus menggunakan kurikulum dari Departemen Pendidikan Nasional dengan tambahan Sibghah Al Washliyah. Sementara untuk jenis MI, MTs, dan MA, Al Washliyah menggunakan kurikulum Departemen Agama dengan tambahan Sibghah Al Washliyah. Untuk jenis TK, madrasah 
al-Qismul 'Aly (MAQ), dan madrasah Aliyah Muallimin (MAM), $\mathrm{Al}$ Washliyah menggunakan kurikulum diniyah Al Washliyah. Di samping itu, dalam buku tersebut diamanahkan bahwa pendidikan Dasar dan Menengah Al Washliyah wajib memuat mata pelajaran tentang; Pendidikan Agama Islam; Pendidikan Pancasila dan Kewarganegaraan; Bahasa; Matematika; Sains; Seni Budaya dan Keterampilan; Pendidikan Jasmani dan Kesehatan; Muatan Lokal; dan $\mathrm{Ke}-\mathrm{Al}$ Washliyahan. ${ }^{48}$

Berdasarkan aturan normatif itu, sesungguhnya yang diamanahkan untuk menggunakan kurikulum diniyah $\mathrm{Al}$ Washliyah adalah madrasah yang berbentuk muallimin dan al-Qismul 'Aly. Namun, yang menarik perhatian adalah temuan di lapangan menunjukkan madrasah Al Washliyah yang $100 \%$ menolak kurikulum SKB 3 Menteri Departemen Agama dan bertahan $100 \%$ dengan kurikulum diniyah Al Washliyah adalah madrasah tsanawiyah yang bukan muallimin dan al-qismul Aly, yang dalam hal ini adalah madrasah Tsanawiyah (MTs) Diniyah Al

${ }^{48}$ PB Al Jam'iyatul Washliyah, Peraturan Sistem Pendidikan Al Washliyah, h. 9.
Washliyah Belawan dan madrasah Tsanawiyah Al Washliyah Tanjung Morawa.

\section{b. Modifikasi Kurikulum SKB 3 Menteri Departemen Agama}

Saat ini, sebagian madrasah Al Washliyah menerapkan kurikulum yang berorientasi pada sistem pendidikan Nasional dan sistem pendidikan Al Washliyah sekaligus. Pasca belakunya SKB 3 Menteri, sebagian dari madrasah Al Washliyah yang berupaya mempertahankan tradisi kitab kuning itu digolongkan sebagai madrasah yang memadukan antara sistem salaf dan khalaf. Pendidikan sistem salaf adalah sistem pendidikan yang mengajarkan berbagai keilmuan Islam yang bersumber dari kitab kuning, meliputi bidang studi: tauhid, tafsîr, hadis , bahasa Arab, fiqih, tarikh, dan akhlak. Kurikulum dalam sistem salaf ini berdasarkan kemudahan dan kompleksitas masalah yang dibahas dalam kitab. Sistem yang digunakan adalah sistem berjenjang, yaitu dari tingkat awal, menengah, dan tingkat lanjut. Sementara sistem khalaf yang diterapkan pada madrasah $\mathrm{Al}$ Washliyah adalah sistem madrasah SKB 3 Menteri 
INTIQAD: JURNAL AGAMA DAN PENDIDIKAN ISLAM

ISSN 1979-9950 (print) || ISSN 2598-0033 (online), http://jurnal.umsu.ac.id/index.php/intiqad

DOI: 10.30596/intiqad.v\%vi\%i.3752

Vol. 11, No. 2 (Desember 2019)

yang menerapkan kurikulum namun tetap mempertahankan

Kementerian Agama Republik kekhasannya mengkaji kitab-kitab

Indonesia. Dalam upaya peningkatan Turast. Madrasah ini menerapkan tafaqquh fî ad-dîn bagi kalangan siswa, kurikulum yang berorientasi pada sistem maka setiap kajian lebih diarahkan pada pendidikan Nasional dan sistem kitab kuning. ${ }^{49}$

Model pendidikan yang berupaya memadukan antara sistem salaf (kurikulum diniyah Al Washliyah) dan khalaf (Kurikulum SKB 3 Menteri) ini sebagaimana misalnya diterapkan di madrasah Tsanawiyah (MTs) Muallimin UNIVA Medan, yang secara formal menggunakan kurikulum KTSP, namun dalam praktiknya berupaya menyusupkan kitab kuning (turats) dalam pembelajarannya.

Sejak tahun 1983 madrasah Muallimin UNIVA Medan yang masa belajarnya enam tahun dipisahkan menjadi dua yaitu madrasah Tsanawiyah Muallimin UNIVA Medan dan madrasah Aliyah Muallimin UNIVA Medan sesuai dengan surat keputusan kantor wilayah Departemen Agama Propinsi Sumatera Utara. Sejak itu antara madrasah Tsanawiyah dan Madrasah Aliyah Muallimin masing-masing berdiri sendiri, dimana MTs Muallimin UNIVA Medan menganut SKB 3 Menteri,

\footnotetext{
${ }^{49}$ Rozali, Tradisi Keulamaan, h. 46.
}

pendidikan Al Washliyah sedangkan pembelajarannya menganut keterpaduan antara kemampuan ilmiah dan kemampuan amaliyah. ${ }^{50}$

Kurikulum Tingkat Satuan Pendidikan (KTSP) MTs Muallimin UNIVA Medan merupakan kurikulum modifikasi dari dua kurikulum, yaitu memadukan KTSP dan kurikulum Diniyah Al Washliyah. Dengan pemaduan ini, diharapkan terjadi sinergi yang kuat antara pembelajaran umum dengan diniyah yang bermuara pada perwujudan karakter peserta didik yang bermutu. Modifikasi kurikulum ini dipandang sangat bermanfaat bagi siswa agar mereka dapat menggapai; (a) permasalahan agama khususnya ibadah, isu lokal, Nasional, kawasan, dunia, sosial, ekonomi, lingkungan dan etika; (b) kemampuan menilai secara kritis perkembangan ilmu pengetahuan dan teknologi serta dampaknya; (c) member

50 Dokumen I Kurikulum Madrasah Tsanawiyah Muallimin UNIVA Medan TP. 2017-2018, h. 7. 
INTIQAD: JURNAL AGAMA DAN PENDIDIKAN ISLAM

ISSN 1979-9950 (print) || ISSN 2598-0033 (online), http://jurnal.umsu.ac.id/index.php/intiqad

DOI: 10.30596/intiqad.v\%vi\%i.3752

Vol. 11, No. 2 (Desember 2019)

sumbangan terhadap keberlangsungan perkembangan sains dan teknologi; (d) memilih karir yang tepat. Oleh karenanya, kurikulum KTSP modofikasi di MTs Muallimin UNIVA Medan lebih menekankan agar siswa menjadi pelajar religious, berkarakter, aktif, dan luwes dalam berkehidupan. ${ }^{51}$

\section{c. Pemaduan Kurikulum Diniyah dan}

Kurikulum SKB 3 Menteri

Departemen Agama.

Meskipun secara normatif, $\mathrm{Al}$ Washliyah telah menetapkan bahwa madrasah Muallimin dan al-Qismul 'Aly menggunakan kurikulum diniyah Al Washliyah, namun kenyataan di lapangan menunjukkan bahwa tidak semuanya bisa bertahan $100 \%$ menggunakan kurikulum diniyah itu. Alasan paling sederhana adalah dengan munculnya kurikulum SKB 3 Menteri madrasah Al Washliyah baik Muallimin maupun al-Qismul 'Aly dihadapkan pada kondisi yang dilematis antara dua pilihan. Pertama, jika bertahan dengan kurikulum diniyah $100 \%$, maka mereka tidak akan mendapat

\footnotetext{
${ }^{51}$ Dokumen I Kurikulum Madrasah Tsanawiyah Muallimin UNIVA Medan TP. 2017-2018, h. 3.
}

pelayanan baik yang bersifat administratif maupun berupa bantuanbantuan dana dari pemerintah. Kedua, jika mengikuti SKB 3 Menteri, maka amanah organisasi dan cita-cita sebagai madrasah Al Washliyah yang khusus membina kader ulama tidak tercapai. Hal ini sebagaimana diakui oleh muallim Hamidy Nur sebagai berikut:

Saat ini jumlah madrasah semakin banyak, sehingga persaingan mendapatkan siswa pun semakin ketat. Zaman sekarang, orang ketika melihat madrasah, yang jadi pertimbangan buat mereka bukan lagi hanya sekedar kurikulum, tapi mereka sudah melihat apakah fasilitasnya lengkap atau tidak, ada atau tidak beasiswa yang bisa diberikan madrasah, seperti dana BOS dan lain-lain. Maka menghadapi keadaan seperti ini lah kadang yang membuat kita jadi dilemma. Di satu sisi, kalau tidak mengikuti kurikulum SKB 3 Menteri Departemen Agama, maka kita tidak akan bisa memperoleh bantuan fasilitas dan dana BOS itu, sementara di sisi yang lain kalau kita menerimanya dan meninggalkan pengajaran kitabkitab sebagaimana yang terdapat pada kurikulum diniyah $\mathrm{Al}$ Washliyah, maka kita pun akan kehilangan jati diri sebagai madrasah yang diharapkan masyarakat dan para ulama pendahulu Al Washliyah sebagai 
madrasah pencipta calon kaderkader ulama. ${ }^{52}$

Menghadapi keadaan yang dilematis itu, maka upaya yang dilakukan oleh madrasah Al Washliyah adalah dengan menerapkan dua kurikulum sekaligus, yaitu kurikulum SKB 3 Menteri dan kurikulum diniyah Al Washliyah dengan strategi mengurangi porsi jam belajar untuk mata pelajaran-mata pelajaran tertentu dan menambahkan porsi jam belajar untuk mata pelajaran-mata pelajaran tertentu yang dipandang lebih utama. Dalam hal ini, madrasah harus rela kehilangan atau melepas sebagian dari tradisi yang dimiliki demi untuk mempertahankan eksistensinya.

\section{e. Menghidupkan Program-program}

\section{Ekstrakurikuler}

Upaya untuk mempertahankan tradisi pembelajaran kitab kuning di madrasah-madrasah Al Washliyah juga dilakukan melalui berbagai program kegiatan ekstrakurikuler. Sejauh temuan peneliti, terdapat beberapa bentuk ekstrakurikuler yang dipandang sebagai

${ }^{52}$ Hamidy Nur, Kepala Madrasah Aliyah Muallimin UNIVA Medan, Wawancara di Medan pada tanggal 07 Desember 2018. bentuk upaya mempertahankan ciri khas madrasah Al Washliyah sebagai berikut:

a) Program Les Qira'atul Kutub

Salah satu ekstrakurikuler yang diterapkan untuk memperkuat kemampuan membaca kitab kuning pada siswa madrasah-madrasah Al Washliyah adalah program Qira'atul Kutub. Pada madrasah Tsanawiyah Muallimin UNIVA Medan, program Qira'atul Kutub dilakukan secara rutin setiap hari Rabu dan Jumat pukul 14.30 sampai dengan 16.00, dimana hal ini bersifat wajib bagi seluruh siswa kelas IX, sementara bagi siswa yang kelas VII dan VIII hanya bersifat pilihan. Hal ini dijelaskan sebagai berikut:

Salah satu kelebihan yang kita targetkan di madrasah ini adalah kemampuan siswa dalam membaca kitab-kitab kuning (turats). Jadi, kita harus membekali mereka dengan kemampuan dasar dalam membacanya. Kita menginginkan setiap siswa yang tamat dari madrasah ini sudah mampu membaca kitab kuning, sehingga kita buatlah program qira'atul kutub ini. Dalam qira'atul kutub ini dijelaskan kepada mereka i'rab dari setiap kata yang diajarkan terkait dengan kitab yang dibahas seperti fiqih, tafsir, tauhid dan lain-lain. ${ }^{53}$

\footnotetext{
53 Muhayyan, WKM I Madrasah Tsanawiyah Muallimin UNIVA Medan,
} 
Sebelum latihan langsung membaca kitab, para siswa terlebih dahulu dibekali dengan materi nahu dan șaraf selama masa dua bulan.

b) Program Dauroh Qira'atul Kutub

Bentuk upaya lain untuk melestarikan tradisi pembelajaran kitab kuning di madrasah Al Washliyah adalah dengan menggelar dauroh qira'atul kutub. Penerapan program dauroh ini sebagaimana misalnya ditemukan di madrasah Aliyah Al Washliyah 12 Perbaungan, di mana pada momenmomen tertentu dilaksanakan seperti pada momen libur sekolah. Pada setiap masa libur, pihak madrasah biasanya membuka pendaftaran bagi setiap siswa yang berminat mengikuti dauroh qira'atul kutub. Pada dauroh ini, para siswa diwajibkan menginap di madrasah layaknya latihan kader dasar selama 3 hari. Adapun bahan bacaan dalam program ini adalah membaca kitab "Mau'izatul Mukminîn". Pada momen ini siswa dilatih untuk mampu menerapkan kaidah-kaidah ilmu-ilmu alat, khususnya nahu dan șaraf di dalam

Wawancara di Medan pada tanggal 12 Desember 2018. praktik membaca kitab mau'iẓotul mukminîn secara langsung.

c). Program Gelar Prestasi dan Pentas Seni

Kegiatan ekstrakurikuler selain program daurah yang ditujukan untuk memperdalam kemampuan dasar baca kitab kuning di madrasah Aliyah Al Washliyah 12 Perbaungan adalah kegiatan "Gelar Prestasi dan Pentas Seni”. Kegiatan ini dilaksanakan secara rutin setiap akhir tahun yaitu pada setiap bulan Desember. Dalam kegiatan ini ada beberapa jenis perlombaan yang digelar dimana salah satu jenis perlombaannya adalah lomba qira'atul kutub. Tujuan kegiatan ini digelar adalah untuk lebih memotivasi para siswa agar terus mengasah kemampuan mereka dalam membaca kitab Arab gundul. Hal ini sebagaimana dijelaskan sebagai berikut:

Untuk memicu semangat siswa dalam mempelajari ilmu-ilmu alat itu kita juga membuat program perlombaan qira'atul kutub yang kita istilahkan dengan gelar prestasi dan pentas seni. Sebenarnya banyak jenis yang diperlombakan seperti syarhil quran, fahmil quran, dan olah raga, tetapi yang paling diutamakan adalah lomba qira'atul kutub. Lomba ini diikuti oleh siswa-siswa lain dari berbagai madrasah yang ada di wilayah Serdang Bedagai, dan ini 
sudah kita laksanakan selama tujuh tahun terahir, sejak dari tahun 2014 hingga saat ini. ${ }^{54}$

Kegiatan ini terbuka untuk umum dan diikuti oleh berbagai madrasah yang ada di wilayah Kabupaten Serdang Bedagai. Dalam kegiatan ini ada 4 jenis perlombaan yang dilombakan yaitu loma qira'atul kutub, lomba nasyid, lomba cerdas cermat, dan lomba olah raga. Menurut mulalim Jumain kegiatan ini memang didesain dengan tujuan utama agar para siswa memiliki motivasi meningkatkan kemampuan mereka dalam membaca kitab, disamping kemampuan yang lain.

d) Program Syarhil Quran dan Fahmil Quran

Melalui program syarhil Quran ini, para siswa dididik agar memiliki kemampuan membaca dan mengkaji kitab-kitab tafsir yang muktabarah. Hal ini merupakan bentuk lain dari upaya mempertahankan tradisi kitab kuning di madrasah Al Washliyah, seperti diterapkan di madrasah Aliyah Muallimin UNIVA dan madrasah al-

54 Afwan Helmi, Guru Mata Pelajaran Fiqih/Koordinator Qira'atul Kutub Madrasah Aliyah Al Washliyah 12 Perbaungan, Wawancara di Perbaungan pada Tanggal 02 Februari 2019.
Qismul 'Aly Ismailiyah dan Madrasah Aliyah Al Washliyah 12 Perbaungan.

Di madrasah Aliyah Muallimin UNIVA Medan, program syarhil dan fahmil quran bertujuan untuk meningkatkan kemampuan siswa dalam memahami dan menjelaskan isi kandungan Alquran dengan memanfaatkan kitab-kitab tafsir para ulama. Program ini disusun secara terencana dengan baik dengan menetapkan Standar kompetensi dan Kompetensi Dasarnya sebagaimana yang dicantumkan dalam dokumen kurikulum madrasah.

e) Pendalaman Nahu Șaraf Bagi Siswa Baru

Secara teoritis, nahu dan șaraf merupakan dua ilmu alat yang termasuk sebagai materi dasar dan posisinya begitu penting, bakna tidak bisa terpisahkan dari pengistilahan kitab kuning. Sebab, apabila ditinjau dari segi kandungan maknanya, sesungguhnya kitab kuning itu dapat dibagi kepada dua; (1) kitab kuning yang berbentuk penawaran atau penyajian ilmu secara polos (naratif) seperti sejarah Islam, tafsir, dll, (2). Kitab kuning yang menyajikan materi berbentuk kaidahkaidah keilmuan seperti, nahu, șaraf, 
INTIQAD: JURNAL AGAMA DAN PENDIDIKAN ISLAM

ISSN 1979-9950 (print) || ISSN 2598-0033 (online), http://jurnal.umsu.ac.id/index.php/intiqad

DOI: 10.30596/intiqad.v\%vi\%i.3752

Vol. 11, No. 2 (Desember 2019)

ushul fiqih, dan musțalah hadits. ${ }^{55}$ Dengan demikian, pengajaran ilmu-ilmu kaidah bahasa Arab juga merupakan bagian dari kitab kuning dimana fungsinya sangat signifikan sebagai prasyarat kemampuan membaca kitab-kitab kuning.

Upaya mempertahankan tradisi pembelajaran kitab kuning di madrasah Al Washliyah adalah melalui program pendalaman nahu dan șaraf. Untuk menjamin berlangsungnya tradisi kitab kuning, maka madrasah Al Washliyah melakukan seleksi terhadap calon siswa yang berorientasi agar siswa-siswa yang masuk ke madrasah telah memiliki kemampuan dasar kaidah bahasa Arab (nahu dan șaraf) sehingga tidak mengalami kesulitan saat mengikuti pembelajaran kitab-kitab sesuai dengan kurikulum diniyah yang diterapkan

\section{Simpulan}

Berdasarkan pembahasan terhadap data penelitian, maka dapat ditarik kesimpulan sebagai berikut:

1. Resistansi tradisi pembelajaran kitab kuning di madrasah-madrasah $\mathrm{Al}$

\footnotetext{
${ }^{55}$ Said Aqil Siradj (et.al), Pesantren Masa Depan Wacana Pemberdayaan dan Transformasi Pesantren (Bandung: Pustaka Hidayah, 1999), h.262.
}

Washliyah bertolak dari pikiranpikiran epistemologis berikut; (a). Pemikiran tentang keutamaan ilmu agama, dimana warga madrasah $\mathrm{Al}$ Washliyah memandang ilmu agama sebagai ilmu yang harus lebih diutamakan daripada ilmu-ilmu lainnya; (b). Pemikiran tentang Penguasaan Kitab Kuning Sebagai Kriteria Utama Ulama, dimana warga madrasah Al Washliyah memandang kemampuan membaca dan mengakses kitab kuning sebagai syarat utama bagi seseorang untuk layak disebut sebagai ulama; (c). Pikiran bahwa kitab kuning sebagai bagian dari sibgah (ciri khas) Al Washliyah, dimana warga Al Washliyah memandang kitab kuning itu merupakan roh yang melekat pada organisasi Al Washliyah; (d). Konsekwensi dari pengikatan diri pada Aliran Ahl al-Sunnah Wa alJamâ'ah dalam aqidah dan mazhab Syafi'i dalam bidang fiqih, dimana warga madrasah Al Washliyah dengan sendirinya harus mampu menguasai karya-karya ulama Ahl al-Sunnah wal Jamâ'ah dan mazhab Syafi'i untuk bisa tetap mempertahankan tradisi pengamalan 
ISSN 1979-9950 (print) || ISSN 2598-0033 (online), http://jurnal.umsu.ac.id/index.php/intiqad

DOI: 10.30596/intiqad.v\%vi\%i.3752

Vol. 11, No. 2 (Desember 2019)

agama yang sejalan dengan Ahl alSunnah Wa al-Jamâ'ah dan Mazhab Syafi'i; (e). Pikiran tentang ketidakmampuan umat melakukan berijtihad dan keyakinan pada hasilhasil Ijtihad ulama-ulama terdahulu, dimana warga madrasah $\mathrm{Al}$ Washliyah memandang ketidakmampuan umat saat ini berijtihad sehingga mereka dituntut untuk mengikuti pendapat ulamaulama imam mazhab, yang syaratnya adalah kemampuan membaca kitab-kitab ulama imam mazhab tersebut.

2. Upaya resistansi tradisi pembelajaran kitab kuning di madrasah-madrasah Al Washliyah dilatar belakangi oleh faktor sosialreligious dengan beberapa variable yaitu; (a). Adanya upaya pendangkalan materi pelajaran ilmu agama, dalam hal ini dipandang dilakukan pemerintah lewat Departemen Agama, khususnya pasca pemberlakuan kurikulum SKB 3 Menteri; (b). Terjadinya krisis ulama, baik secara kualitas maupun kuantitas; (c). Muncul dan semakin berkembangnya aliran-aliran pemikiran atau paham-paham keagamaan; (d). Adanya dampak negatif perkembangan teknologi internet terhadap penurunan kualitas bahan ceramah agama yang disampaikan kepada umat.

3. Bentuk-bentuk resistansi tradisi pembelajaran kitab kuning yang terjadi di madrasah Al Washliyah beragam yaitu ; (a) Konsisten mempertahankan kurikulum diniyah Al Washliyah $100 \%$ dan menolak untuk menerapkan kurikulum Departemen Agama; (b). Melakukan modifikasi kurikulum, dimana madrasah $\mathrm{Al}$ Washliyah menerima kurikulum Departemen Agama, tetapi dengan merekayasa materi/bahan ajar di lapangan; (c) Menerapkan pembelajaran dengan memadukan kurikulum diniyah $\mathrm{Al}$ Washliyah dan kurikulum Departemen Agama dengan perbandingan porsi $70 \%$ kurikulum diniyah dan $30 \%$ kurikulum Departemen Agama, begitu juga pada madrasah yang lain perbandingannya $50 \%$ kurikulum diniyah dan $50 \quad \%$ kurikulum Departemen Agama; (d). Mengembangkan program-program ekstrakurikuler seperti; Eskul 


\section{INTIQAD: JURNAL AGAMA DAN PENDIDIKAN ISLAM}

ISSN 1979-9950 (print) || ISSN 2598-0033 (online), http://jurnal.umsu.ac.id/index.php/intiqad DOI: $10.30596 /$ intiqad.v\%vi\%i.3752

Vol. 11, No. 2 (Desember 2019)

Qira'atul Kutub, Eskul Daurah Qira'atul Kutub, Eskul Pendalaman Nahu dan Saraf Bagi Siswa Baru, Eskul Gelar Prestasi dan Pentas Seni dimana salah satu bidang perlombaan adalah bidang Qira'atul Kutub, Eskul Fahmil dan Syarhil Quran.

\section{Daftar Pustaka}

Azra. Azyumardi. (1999). Islam Reformis, Dinamika Intelektual dan Gerakan. Jakarta: Raja Grafindo Persada.

\section{. (2001). Pendidikan Islam:}

Tradisi dan Modernisasi Menuju Milenium Baru. Jakarta: Kalimah.

Amin, Ahmad. (1974). Duhah al-Islâm. Kairo: Maktabah Nahḍah alMișriyyah.

Al-Baijûrî. (tt). Ibrâhîm Bin Muhammad, Tuhfah al-Murîd 'Ala Jauharah al-Tauhîd. Haramain.

Al-Ghazâlî. (tt). Abû Hâmid, Ihyâ' 'Ulûm al-Dîn. Kairo: Dâr Ihyâ' al-Kutûb al-'Arabiyah.

Asari, Hasan. (2007). Menyingkap Zaman Keemasan Islam.

Bandung: Citapustaka Media.
(2008). Sejarah Pendidikan

Islam: Membangun Relevansi

Masa Lalu dengan Masa Kini dan Masa Depan. Medan:

Perdana Publishing.

(2007).Menyingkap Zaman
Keemasan Islam. Bandung:
Citapustaka Media.
. (2002). Modernisasi Islam: Tokoh, Gagasan, dan Gerakan. Bandung: Citapustaka Media.

Arifin, Imron. (1993) Kepemimpinan Kiai, Kasus: Pondok Pesantren Tebuireng. Malang:

Kalimasahada Press.

Al-Jurjâni. Abi Hasan Ali Bin Muhammad bin Ali al-Husainy. (1434). At-Ta'rîfât. Beirut: Dar al-Kutub Ilmiyyah.

Al-Jabiri, Muhammad Abed. (2000). Post Tradisionalisme Islam, Terjemahan. Yogyakarta: LKiS.

Al-Kurdy, Muhammad Amin. (tt). Tanwîr al-Qulûb Fî̀ Mu'âmaltin Allâm al-Guyûb. Indonesia: Dâr Ihyâ' al-Kutub al-Arabiyah.

Anotasi. (2007). Kitab Kunig, Khazanah Intelektualisme Pesantren di Indonesia. Jakarta: Darul Ilmi. 


\section{INTIQAD: JURNAL AGAMA DAN PENDIDIKAN ISLAM}

ISSN 1979-9950 (print) || ISSN 2598-0033 (online), http://jurnal.umsu.ac.id/index.php/intiqad

DOI: $10.30596 /$ intiqad.v\%vi\%i.3752

Vol. 11, No. 2 (Desember 2019)

Ali, Lukman. (1999). Kamus Besar

Bahasa Indonesia. Jakarta: Balai

Pustaka.

Al-Mawardi. Abî al-Hasan'Ali bin

Muhammad bin Habîb al-Bashri.

(1995). Âdab al-Dunyâ wa al-

Dîn. Beirut: Dâr al-Fikr.

An-Naysabûrî, Imâm Abi al-Husain

Muslim bin al-Hajjâj al-Qusyairî.

(tt). Śahih Muslim, kitab Fadâ'il

as-Ṣahâbah, Bab Fadâ'il as-

Sahâbah Summallajîna

Yalûnahum Ś Summallajîna

Yalûnahum. Indonesia: Maktabah

Dahlan.

Al-Rasyidin. "Pembelajaran Kitab

Kuning di Pesantren

Mustafawiyah, Mandailing

Natal"dalam Journal Of

Contemporary Islam And Muslim

Societies. Vol. 1 No. 1 (2017).

Arikunto, Suharsimi. (2002). Prosedur

Penelitian Suatu Pendekatan

Praktek. Jakarta: Rineka Cipta.

Abdul Wahid, Ramli. (2014). Peranan

Islam dalam Menghadapi Era

Globalisasi Sekuler. Bandung:

Citapustaka Media.

Arifin, Ed. Imron. (1996). "Penelitian

Kualitatif Dalam Ilmu-Ilmu
Sosial Dan Keagamaan”.

Malang: Kalama sahada Press.

Barnadib, Imam. (2005). Filsafat Pendidikan Tinggi dalam Ridwan Nasir, Mencari Tipologi Format Pendidikan Ideal. Yogyakarta: Pustaka Pelajar.

Bruinessen, Martin Van. (1992).

"Pesantren and Kitab Kuning Maintenance and Continuation Of Religius Learning”.

. (1995). Kitab Kuning, Pesantren dan Tarekat. Bandung: Mizan.

. (1999). Traditionalist Muslims in A Modernizing World: The Nahdatul Ulama and Indonesia's New Order Politics, Factional Conflict, and The Search for A New Discourse, Diterjemahkan Farid Wajidi. Yogyakarta: LKiS Yogyakarta.

Dhofier, Zamakhsyari. (1982). Tradisi Pesantren Studi tentang Pandangan Hidup Kiai. Jakarta: LP3ES.

Daulay, Haidar Putra. (2012).

Pendidikan Islam dalam Sistem Pendidikan Nasional di Indonesia. Jakarta: Kencana.

. (2007). Sejarah Pertumbuhan dan Pembaruan Pendidikan 


\section{INTIQAD: JURNAL AGAMA DAN PENDIDIKAN ISLAM}

ISSN 1979-9950 (print) || ISSN 2598-0033 (online), http://jurnal.umsu.ac.id/index.php/intiqad

DOI: 10.30596/intiqad.v\%vi\%i.3752

Vol. 11, No. 2 (Desember 2019)

Islam di Indonesia. Jakarta:

Kencana.

—. (2012). Pendidikan Islam dalam Sistem Pendidikan Nasional di Indonesia. Jakarta: Kencana.

Dokumen I Kurikulum Madrasah Aliyah Muallimin Univa Medan TP. 2018-2019

Dokumen Kegiatan Qira'atul Kutub Madrasah Aliyah Muallimin Univa Medan Tahun 2018/2019

Dokumen Laporan Kegiatan Olimpiade

Nahu \& Sharaf ke-2 Tahun 2018 Madrasah Aliyah Al Washliyah se Sumatera Utara.

Departemen Agama RI. (2005). Al-

Qur'an dan Terjemahannya.

Bandung: PT Syaamil Cipta Media.

Djumhur. (1975). Bimbingan dan Penyuluhan di Sekolah.

Bandung: Ilmu.

El Hadidhy. Syahrul AR dkk. (2005).

Pendidikan Ke Al Washliyahan 3.

Medan: Majelis Pendidikan dan

Kebudayaan Al Washliyah

Sumatera Utara.

Efendi. (2016). Pendidikan Islam Transformatif Ala KH.
Abdurrahman Wahid. Jakarta: Guepedia.

Effendi, Djohan. (2010). Pembaruan Tanpa Membongkar Tradisi. Jakarta: Penerbit Buku Kompas.

Furchan, Arif. (1998). "Pengantar Metodologi Penelitian Kualitatif" (Surabaya: Usaha Nasional, 1992), M. Nasir, Metode Penelitian. Jakarta: Ghalia Indonesia.

Hadi, Sutrisno. (1989). "Metodologi Reseach”. Yogyakarta: Andi Offset.

Hajar, Ibnu. (2009). Kiai di Tengah Pusaran Politik Antara Petakadan Kuasa. Yogyakarta: IRCiso.

Hamalik, Oemar. (2001). Kurikulum dan Pembelajaran. Jakarta: Bumi Aksara.

Hasbullah. (2010). Otonomi Pendidikan: Kebijakan Otonomi Daerah dan Implikasinya terhadap Penyelenggaraan Pendidikan. Jakarta: Rajawali Pers.

(1995). Sejarah Pendidikan Islam di Indonesia. Jakarta: Raja Grafindo Persada.

(1999). Sejarah Pendidikan Islam di Indonesia: Lintasan 
INTIQAD: JURNAL AGAMA DAN PENDIDIKAN ISLAM

ISSN 1979-9950 (print) || ISSN 2598-0033 (online), http://jurnal.umsu.ac.id/index.php/intiqad DOI: 10.30596/intiqad.v\%vi\%i.3752

Vol. 11, No. 2 (Desember 2019)

Sejarah Pertumbuhan dan

Edukasi, dan Filosofi. Medan:

Perkembangan. Jakarta: Raja

Perdana Publishing.

Grafindo Persada.

Khazanah Kitab Kuning di

Huda, Nor. (2015). Sejarah Sosial

Intelektual Islam di Indonesia.

Jakarta: Raja Grafindo

Persada.

Madrasah Al Jam'iyat Al

Washliyah, dalam Jurnal Al-

Thariqah Vol.2, No. 2 (2017).

Peran Al Jam'iyatul Washliyah

Ibn Katsir, Abu al-Fida' Ismail. (1989). dalam Merevitalisasi Mazhab

Tafsîr Alquran al-Aẓhîm. Syafi'I di Era Kontemporer.

Beirut: Dar al-Ma'rifah.

Indrawan, Irdjus. (2015). Pengantar

Manajemen Sarana Prasarana

Sekolah. Yogyakarta: Justicia Islamica Vol. 13, No. 1, (2016).

Deepublish.

Washliyah:1930-2015. Medan:

Ja'far. (2015). Tradisi Intelektual Al

Perdana Publishing.

Washliyah: Biografi Ulama

Kharismatik dan Tradisi

Keulamaan. Medan: Perdana

Publishing.

(2011). Al-Jam'iyatul
Washliyah Potret Histori, 